\title{
Pulsed flows observed during an interval of prolonged northward IMF
}

\author{
G. Provan, M. Lester, A. Grocott, and S. W. H. Cowley \\ Department of Physics and Astronomy, University of Leicester, University Road, Leicester LE1 7RH, UK \\ Received: 13 August 2004 - Revised: 10 December 2004 - Accepted: 16 February 2005 - Published: 3 June 2005
}

\begin{abstract}
On the 22 December 2002 the interplanetary magnetic field (IMF) was directed northwards for more than $12 \mathrm{~h}$. The Northern and Southern Hemisphere SuperDARN radars were used to study global high-latitude convection during this interval, complemented by data from the ACE and DMSP F13 spacecraft. The relative magnitudes of the IMF $\mathrm{B}_{y}$ and $\mathrm{B}_{z}$ components varied during this period. When the magnitude of the $\mathrm{B}_{y}$ component was comparable with or dominated the $\mathrm{B}_{z}$ component, signatures of simultaneous low-latitude and lobe reconnection were observed. Specifically two "standard" merging cells were observed in both hemispheres. In the Northern Hemisphere a high-latitude lobe cell was observed within the dusk merging cell, and there was also evidence of a narrow viscous cell located equatorward of this lobe cell. We observed the ionospheric signatures of flux transfer events (FTEs) in both the Northern and Southern Hemispheres, occurring with a periodicity of $\sim 15 \mathrm{~min}$. In the Northern Hemisphere the FTEs were associated with a stepwise equatorward progression of the equatorward boundary of radar backscatter on the dayside. When the IMF $\mathrm{B}_{z}$ component was predominantly greater than the IMF $\mathrm{B}_{y}$ component, we observed a four-cell convection pattern in the Northern Hemisphere, with pulses of reverse reconnection and an associated stepwise poleward retraction of the equatorward boundary of radar backscatter occurring every $\sim 25 \mathrm{~min}$. These observations are consistent with pulsed lobe reconnection occurring in both hemispheres, closing open flux and adding closed flux to the dayside magnetopause. So, during this northward IMF interval the location of the sites of reconnection between the IMF and the Earth's magnetosphere, and thus the form of reconnection process, varied with changing IMF conditions. However, the reconnection remained pulsed, with lobe-only reconnection having a significantly longer periodicity compared with simultaneous lobe and low-latitude reconnection.
\end{abstract}

Keywords. Magnetospheric physics (Solar windmagnetosphere interactions; Magnetosphere-ionosphere interactions; Polar cap phenomena)

Correspondence to: G. Provan

(gp3@ion.le.ac.uk)

\section{Introduction}

Over the years much attention has been paid to the process of magnetic reconnection occurring at the dayside magnetopause during intervals of southward interplanetary magnetic field (IMF), leading to a greatly enhanced understanding of this process and of the pulsed flux transfer events (FTEs) that are observed during such intervals. The first observations of impulsive dayside reconnection were made using space instruments (Haerendel et al., 1978; Russell and Elphic, 1978, 1979). More recently large instrumental advances have resulted in detailed studies of the ionospheric response to dayside reconnection (e.g. Sandholt et al., 1989; Lockwood et al., 1990; Elphic et al., 1990), with the near global coverage of the SuperDARN chain of HF radars making these instruments ideal for studying the large-scale ionospheric response (Pinnock et al., 1995; Provan et al.,1998; McWilliams et al., 2000).

Currently the process of dayside reconnection during intervals of Northward IMF is a "hot topic" of discussion. For example, Frey et al. (2003), presented two case studies of magnetic reconnection during northward IMF. Their observations were consistent with reconnection at the Earth's high-latitude magnetopause being driven directly by the solar wind, and remaining continuous and even quasi-steady over a period of time. On the other hand, Sandholt et al. (2000) reported bursts of reverse convection and a stepwise poleward motion of radar backscatter during an interval containing a rapid northward turning of the IMF. It is now over forty years since Dungey (1963) first postulated that dayside reconnection could occur during intervals of northward IMF at very high-latitude field lines tailward of the cusp. Dungey's (1963) ideas were later described by Cowley $(1981,1983)$, who presented a pictorial catalogue of physically possible magnetic topologies for lobe reconnection during Northward IMF. Cowley's $(1981,1983)$ pictorial catalogue is presented here in Fig. 1, and has previously been discussed by Crooker (1992). Dungey's (1963) model of lobe reconnection is presented in Fig. 1a. Dungey (1963) discussed a totally closed magnetosphere, with one magnetosheath field line reconnecting with the same closed 


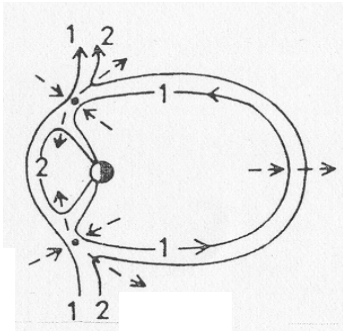

(a)

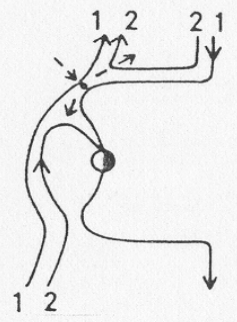

(b)

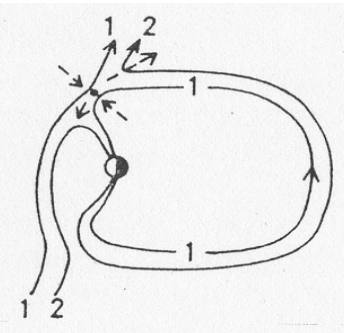

(c)

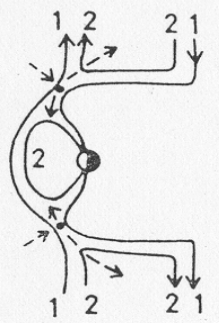

(d)

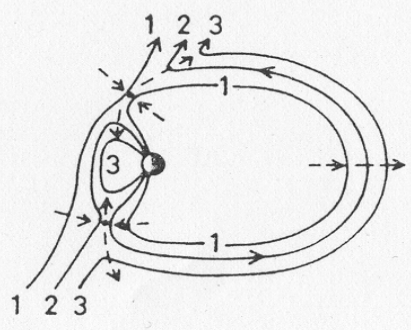

(e)

Fig. 1. Cowley's $(1981,1983)$ pictorial presentation of five different physically possible topologies for lobe reconnection during Northward IMF.

magnetospheric field line in both the Northern and Southern Hemisphere. The result is the transfer of closed nightside flux to closed dayside flux, with the newly-created magnetospheric field lines on the dayside first being pulled sunwards, due to the magnetic tension of the newly reconnected field lines, before being swept anti-sunward towards the dawn and dusk flanks with the magnetosheath flow. These two opposing forces would result in two reverse-convection cells being created in each hemisphere, with sunward flow over the polar cap and anti-sunward flow at lower latitude. This sense of rotation is opposite to the direction of rotation of high-latitude flows observed under southward IMF conditions.

Figure 1b presents Russell's (1972) suggestion that dayside reconnection during intervals of northward IMF could occur with open field lines in one lobe only, particularly in the presence of an east-west component of the IMF, resulting in the reconfiguration of open magnetic field lines. This merging would also be accompanied by reverse convection, which is decoupled in the two hemispheres. The convection cells created due to lobe merging are typically referred to as lobe cells. Lobe cells are located wholly on open field lines with flux merely being circulated within the polar cap (Burch et al., 1985; Reiff and Burch, 1985).

In Fig. 1c high-latitude lobe merging occurs in only one hemisphere, as also presented in Fig. 1b. But this time the magnetosphere is closed, not open. Thus the effect of the reconnection is to add open flux to the dayside magnetosphere, and the polar-cap should expand. In Fig. 1d Cowley (1981, 1983) describes magnetic reconnection occurring simultaneously in both hemispheres (as also suggested in Fig. 1a). However, this time the magnetosphere is open, and the reconnection occurs on open lobe field lines. The net result is to transfer open lobe flux into closed dayside flux, resulting in a shrinking of the polar cap. The nightside polar-cap boundary moves northward with the reverse-cell flow.

Finally, Fig. 1e presents Cowley's (1983) representation of sequential merging in the Northern and Southern Hemispheres. Lobe reconnection first occurs in the Northern Hemisphere, forming an open field line that drapes over the dayside and one that connects to the Southern Hemisphere. Later, the overdraped field line merges with one of the previously opened field lines in the Southern Hemisphere, forming a closed dayside field line and a completely detached field line. Similar sequential merging can also occur in the case of open field lines in the tail, though this is not illustrated in the figure.

First observations of reverse convection were made by Maezewa (1976) who interpreted ground magnetometer signatures in terms of lobe convection. Later, the existence of high-latitude "lobe" reconnection has been verified by in-situ spacecraft observations (Gosling et al., 1991; Kessel et al., 1996). Gosling et al. (1991) reported that during an interval when the IMF $B_{z}$ component was slightly negative and $\left|\mathrm{B}_{y}\right| \gg\left|\mathrm{B}_{z}\right|$, mixed populations of accelerated magnetosheath and magnetospheric plasma were observed close to the magnetopause boundary, while Kessel et al. (1996) observed sunward flowing protons during reconnection at the high-latitude magnetopause $\left(75^{\circ}\right)$ when the IMF was directed northward. Low-altitude and ground-based observations illustrate that "four cell" convection is typical under northward IMF conditions. The two highest latitude cells are reverse convection cells with sunward flow over the polar cap. At lower latitude two "standard" convection cells are observed, in which the flow rotates in the same direction as ionospheric 
cells observed under southward IMF conditions, with antisunward flow at high latitude and sunward flow at lower latitude. These two lower-latitude cells are often attributed to viscous processes at the magnetopause boundary at lower latitudes (Burke et al., 1979; Potemra et al., 1984; Freeman et al., 1993).

Crooker et al. (1979) stated that for lobe reconnection to occur the northward IMF needs to be near anti-parallel to the geomagnetic field of the tail lobes. The tilt of the Earth's magnetic dipole and the IMF conditions will at times mean that lobe reconnection will be more likely to occur in one hemisphere than the other. The seasonal tilt of the magnetic dipole, as well as the relative magnitude and orientation of the IMF $\mathrm{B}_{y}$ and $\mathrm{B}_{x}$ components, will determine which hemisphere is favoured. Cowley (1983) stated that if the IMF is pointed antisunward (IMF $\mathrm{B}_{x}<0$ ) the Northern Hemisphere is favoured over the southern as a site of reconnection, as the IMF is anti-parallel to the geomagnetic field there. It was suggested that the reconnection in the unfavoured hemisphere may eventually be activated at a later stage, involving the overdraped magnetic flux resulting from reconnection in the favoured hemisphere (as in Fig. 1e). Crooker and Rich (1993) showed that lobe reconnection was much more likely to occur in the summer hemisphere. Lockwood and Moen (1999) illustrated that a large IMF $\mathrm{B}_{x}$ component can alter the effective dipole tilt of the magnetosphere with respect to the IMF, and hence, alter the favoured hemisphere for reconnection. Østgaard et al. (2003) observed two examples of non- conjugate theta auroras, suggesting that the pointing direction of the IMF $\mathrm{B}_{x}$ component resulted in lobe reconnection being favoured in one hemisphere over the other.

The relative magnitude of the IMF $\mathrm{B}_{y}$ component compared to the IMF $\mathrm{B}_{z}$ component will also alter the reconnection process. For example, Cumnock et al. (1992), Freeman et al. (1993), and Knipp et al. (1993) showed that low-latitude reconnection could still occur during intervals of Northward IMF if the IMF $\mathrm{B}_{y}$ component was larger than the IMF $\mathrm{B}_{z}$ component, so that the magnetic shear at the low-latitude magnetopause was sufficient for reconnection to start there. Knipp et al. (1993) and Ruohoniemi and Greenwald (1996) reported a progression of the convection form from a distorted two-cell pattern to a multi-cell pattern with increasing IMF $\mathrm{B}_{z}$ positive.

High-latitude rapid velocity transients are commonly observed in the 1-o-s velocity measurements detected by HF radars. Poleward-moving regions of antisunward flow measured by HF radar, suggested to be associated with FTEs, have been studied at high-time resolution by Pinnock et al. (1995) and Rodger and Pinnock (1997). Provan et al. (1998) employed data from the CUTLASS Finland radar to perform a detailed study of the dynamics and extent of pulsed ionospheric flows (PIFs). These antisunward-moving transient features were identified as the ionospheric signatures of impulsive dayside reconnection i.e. the signature of magnetopause flux transfer events (FTEs) (Russell and Elphic, 1978, 1979). Such impulsive reconnection is believed to be the primary mechanism for the transfer of flux from the Earth's magnetosheath to the magnetosphere (e.g. Milan et al., 2000), and occur generally during intervals of lowlatitude merging when the IMF is directed southwards (e.g. Rijnbeek et al., 1984). However, a recent statistical study by McWilliams et al. (2000) found that one third of the pulsed ionospheric flows observed by the SuperDARN radars occurred under northward IMF conditions. Below we will further study FTEs observed during low-latitude merging when the IMF is directed northwards. By "low-latitude merging" we mean merging occurring equatorward of the openclosed field-line boundary between closed magnetospheric field lines and the unconnected field lines of the IMF. The actual latitude at which this merging occurs, whether "low" or otherwise, is not examined in this paper. The term "lowlatitude" is thus only used to differentiate this merging process from the high-latitude lobe merging observed tailward of the cusp, between the IMF and open field lines of the tail lobe.

In this paper we present a case study of one day of prolonged northward IMF. During this interval, on 22 December 2002, the IMF $B_{z}$ component was pointing continuously northward for more than $12 \mathrm{~h}$, reaching values of up to $18 \mathrm{nT}$. We study the global high-latitude ionospheric flow patterns using the Northern and Southern Hemisphere SuperDARN radars. We also present data from the ACE spacecraft and the F13 DMSP spacecraft. We study the effect of the IMF $\mathrm{B}_{y}$ and $\mathrm{B}_{z}$ components on dayside reconnection processes that occur during this northward IMF interval, giving particular attention to the pulsed nature of this reconnection.

\section{Instrumentation}

The ionospheric convection velocities presented in this study are provided by the Northern and Southern Hemisphere SuperDARN radars, part of the international SuperDARN chain of HF radars (Greenwald et al., 1995). At present there are 9 SuperDARN radars imaging the high-latitude convection in the Northern Hemisphere, and 7 radars in the Southern Hemisphere. Each radar of the system is frequency agile (8-20 MHz), and routinely measures the line-of-sight (1-o-s) Doppler velocity, the spectral width, and the backscattered power from ionospheric plasma irregularities. The radars each form 16 beams of azimuthal separation $3.24^{\circ}$. Each beam is gated into 75 range bins. In the standard operation (normal resolution) mode used here, each gate has a length of $45 \mathrm{~km}$ and the dwell time for each beam is $7 \mathrm{~s}$, giving a full 16 beam scan, covering $52^{\circ}$ in azimuth and over 3000 $\mathrm{km}$ in range (an area of over $4 \times 0^{6} \mathrm{~km}^{2}$ ), every 2 min. During this interval data were available from 6 of the 9 Northern Hemisphere radars i.e. Hankasalmi (f), Iceland East (e), Iceland West (w), Saskatoon (t), Kapuskasing (k), and Prince George (b), and from 5 of the 7 Southern Hemisphere radars i.e. Syowa (j), Syowa East (n), Sanae (d), Halley (h), and Tiger (r). The letters in brackets after the radar names represent the station identification letter. Low altitude particle 


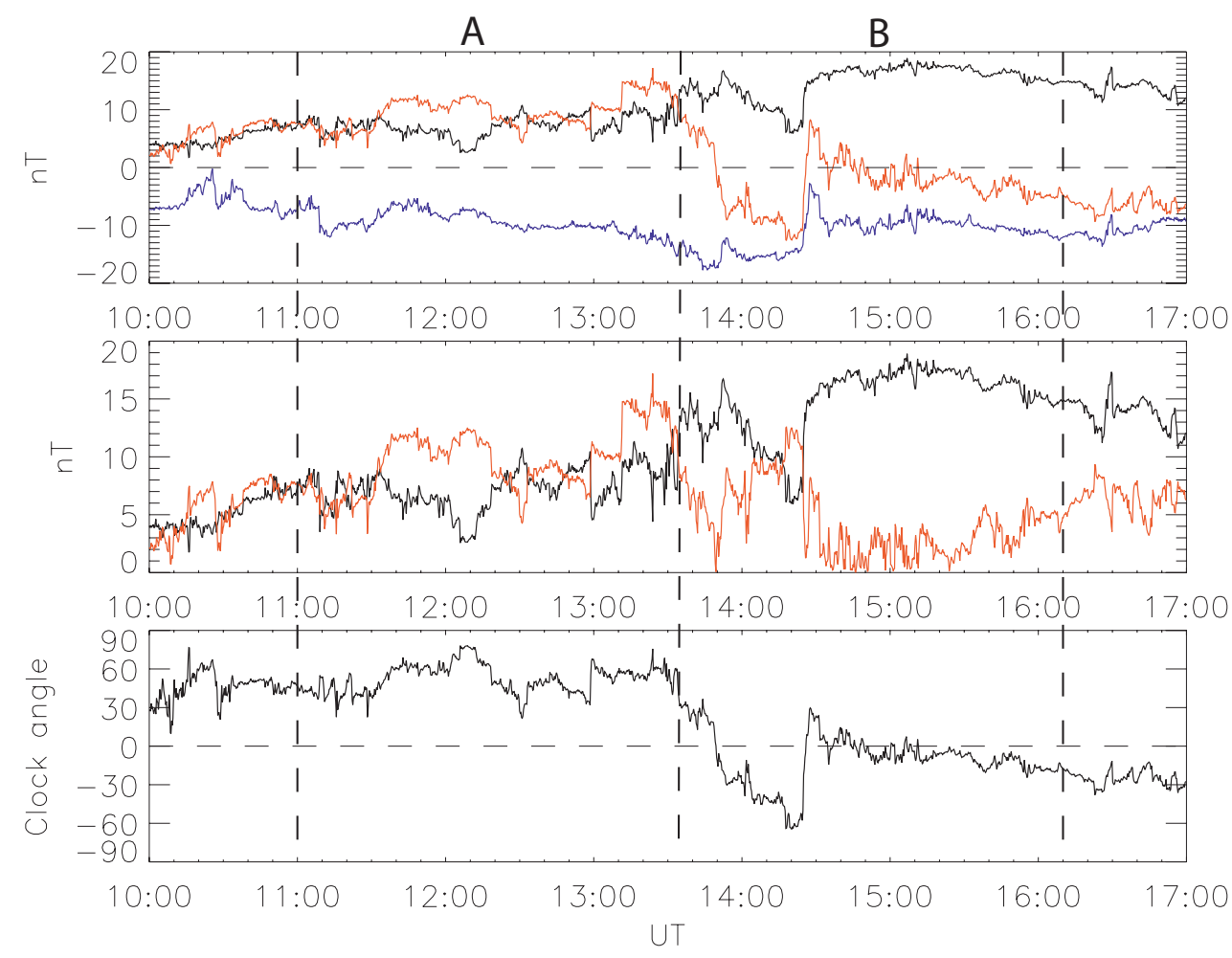

Fig. 2. The IMF conditions observed by the ACE spacecraft from 10:00 to 17:00 UT on 22 December 2002. A 55 min delay time has been added to the plots. The IMF $\mathrm{B}_{x}$ component is coloured blue, the IMF $\mathrm{B}_{y}$ component is coloured red and the IMF $\mathrm{B}_{z}$ component black. Time intervals $\mathrm{A}$ and $\mathrm{B}$ are indicated on the plot by the vertical dashed lines.

precipitation data are provided by the DMSP F13 spacecraft. Hardy et al. (1984) have provided detailed information concerning the detectors. Upstream IMF data is provided by the ACE satellite (Smith et al., 1999).

\section{Data presentation}

\subsection{IMF observations}

The top panel of Fig. 2 presents the IMF conditions from the ACE spacecraft for 22 December 2002 for the time interval 10:00 to 17:00 UT. At 10:00 UT ACE is positioned upstream of the Earth at GSM position $(X, Y, Z)=(241.7,4.4,13) \mathrm{R}_{E}$. A 55 min lag time has been added onto the time scale of the plot, representing the delay between the IMF being observed by the satellite and when it impinges on the magnetopause, calculated using the algorithm of Lester et al. (1993). IMF $\mathrm{B}_{x}$ component is coloured blue, the IMF $\mathrm{B}_{y}$ component red and the IMF $\mathrm{B}_{z}$ component black. The middle panel of Figure 2 presents the absolute magnitude of the IMF $\mathrm{B}_{y}$ and $\mathrm{B}_{z}$ components, again coloured red and black respectively. The bottom panel of Fig. 2 shows the IMF clock angle, calculated as

$\theta=\tan ^{-1}\left(B_{y} / B_{z}\right)$.

As stated previously, one of the main aims of this paper is to study the effect of variations in the IMF conditions on the dayside reconnection process. In order to achieve this we have chosen to study two intervals during this day in detail. The two time intervals are marked with black dashed vertical lines on Fig. 2, and labelled A and B. During both intervals the IMF $\mathrm{B}_{z}$ component remains wholly positive (northward), and the IMF $\mathrm{B}_{x}$ component negative. During interval $\mathrm{A}$, which lasts from 11:00 to 13:35 UT, the IMF $B_{y}$ component is also positive and generally comparable with or larger than the IMF $\mathrm{B}_{z}$ component. The IMF clock angle is thus predominantly $\sim 45^{\circ}$ or larger. During interval $\mathrm{B}$, from 13:35 to 16:10 UT, the IMF $\mathrm{B}_{y}$ component is generally negative and smaller than the IMF $\mathrm{B}_{z}$ component. The first $\sim 55 \mathrm{~min}$ of interval B, however, from 13:35 to 14:30 UT, are characterised by variable magnetic field conditions. The IMF $\mathrm{B}_{y}$ component changes from positive to negative values at 13:50 UT. The IMF $\mathrm{B}_{z}$ component dominates the $\mathrm{B}_{y}$ component except for a few minutes around 14:20 UT, when a strongly negative $\mathrm{B}_{y}$ component results in a clock angle of $\sim-60^{\circ}$. After 14:30 UT the IMF conditions remain fairly stable, with the IMF $\mathrm{B}_{z}$ component significantly larger than the $\mathrm{B}_{y}$ component. During this time the clock angle is consistently small, fluctuating between $-20^{\circ}$ and $15^{\circ}$.

\subsection{SuperDARN observations}

Figure 3 presents 1-o-s velocities from the four Northern Hemisphere radars that observed the most scatter on this 


\section{NORTHERN HEMISPHERE L-O-S VELOCITY, 20021222, 10 TO 17 UT}

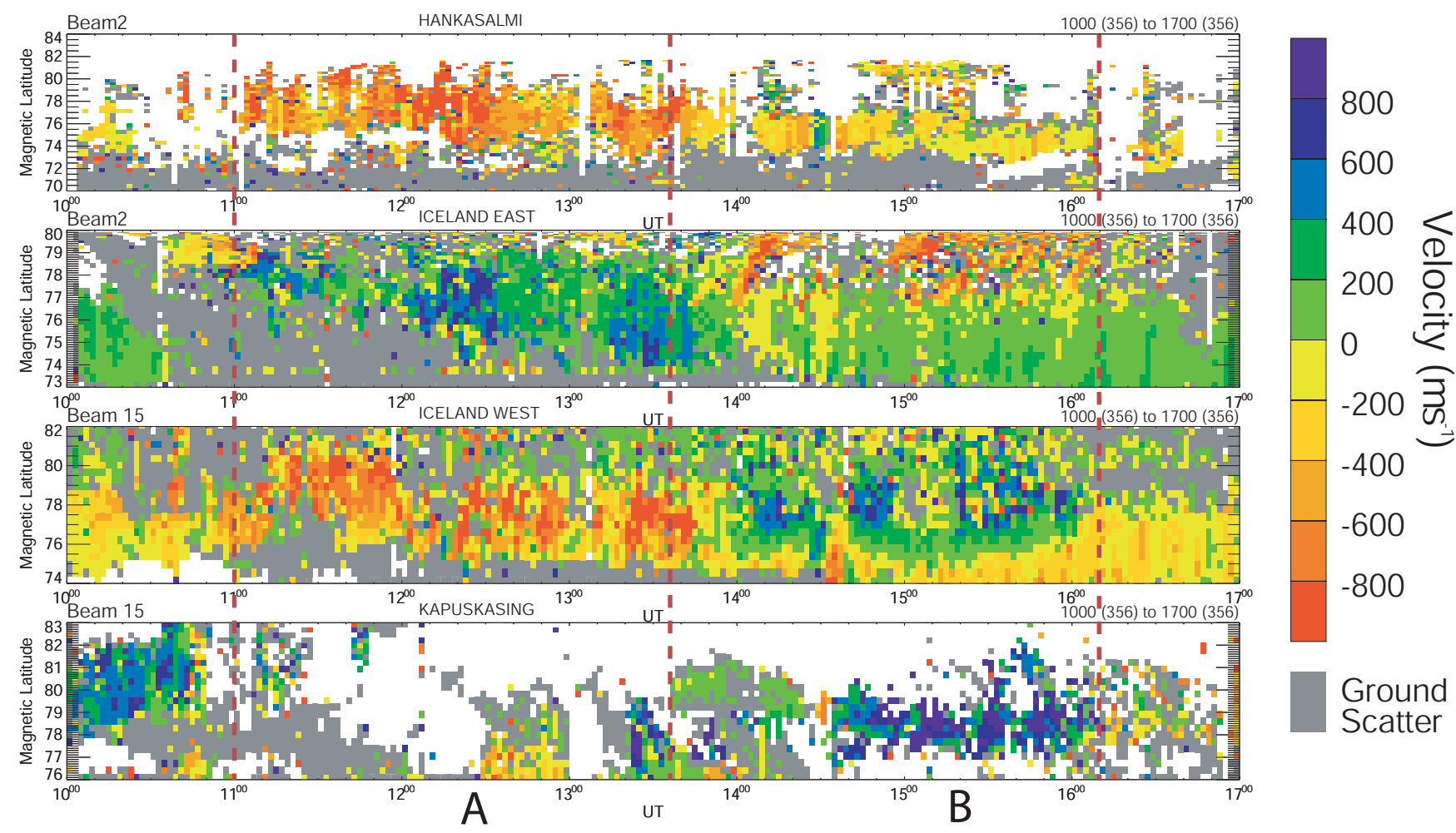

Fig. 3. The 1-o-s velocities from the Hankasalmi (beam 2), Iceland East (beam 2), Iceland West (beam 15) and Kapuskasing (beam 15) radars, from 10:00 to 17:00 UT on 22 December 2002. The plots presents 1-o-s velocity as a function of time, the velocity is colour coded where positive values (green and blue) show flows toward the radar and negative values (yellow and red) show flows away from the radar. Time intervals A and B are indicated on the plot by the vertical dashed lines.

day, Hankasalmi (beam 2), Iceland East (beam 2), Iceland West (beam 15) and Kapuskasing (beam 15), from 10:00 to 17:00 UT. The plots shows colour-coded l-o-s velocity as a function of time, where positive values (green and blue) show flows toward the radar and negative values (yellow and red) show flows away from the radar. The two time intervals A (11:00 to 13:35 UT) and B (13:35 to $16: 10$ UT) are marked on the plot with red dashed vertical lines. Figure 4 presents the 1-o-s velocities from four of the Southern Hemisphere radars for the same time period, Syowa East (beam 5), Syowa (beam 8), Sanae (beam 12), and Tiger (beam 5). Again the two time intervals A and B are marked with red dashed vertical lines on the plot. Figure 5 presents the f-o$\mathrm{v}$ of the selected Northern (Fig. 5a) and Southern (Fig. 5b) Hemisphere radars at 13:00 UT, during interval A. The plots are in MLAT/MLT co-ordinates, with 12:00 MLT being located at the top of the page. The radar beams from which data were presented in Figs. 3 and 4 are marked on the plots with red lines. The plots show that at this time all the four selected Northern Hemisphere radars are located on the dayside, with the selected radar beams at Hankasalmi (f), Kapuskasing (k) and Iceland West $(\mathrm{w})$ all looking toward the cusp region. In the Southern Hemisphere three of the selected radars are on the dayside, with the selected beams of Sanae (d) and Syowa (j) both observing the cusp region. The Tiger (r) radar is located close to local midnight. We will now present a detailed analysis of the ionospheric flows observed during intervals A and $\mathrm{B}$.

\subsection{Interval A}

Figure 3 presents the 1-o-s velocity from beam 2 of the Hankasalmi radar and beam 15 of the Iceland West radar. During interval A these two radar beams are predominantly observing plasma flow near noon (Fig. 5). They observe fast plasma flow moving away from the radar. These flows are observed at high latitudes, between $72^{\circ}$ and $82^{\circ}$ by the Hankasalmi radar and between $75^{\circ}$ and $81^{\circ}$ by the Iceland West radar. These flows appear to have a pulsed nature. The Iceland East radar is located in the post-noon region. Figure 3 also presents the 1-o-s velocity from beam 2 of this radar, this beam is looking in a zonal direction toward dusk. The Iceland East radar is observing strong plasma flows moving towards the radar which are also variable with time. The Kapuskasing radar is located in the morning sector, and is observing little backscatter in this interval.

In the Southern Hemisphere the Syowa East, Syowa and Sanae radars are located on the dayside (Fig. 5). The 1-o-s 


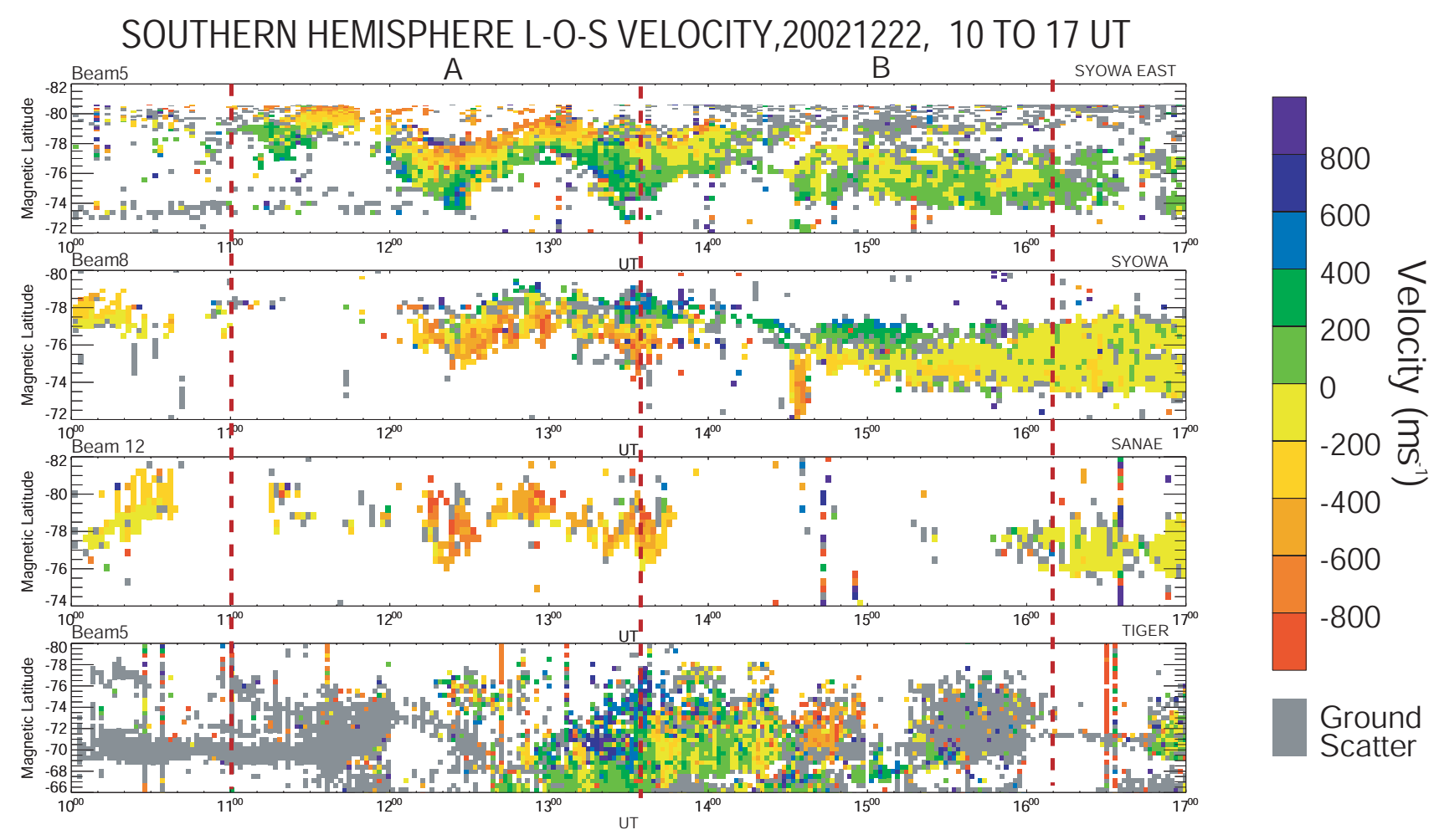

Fig. 4. L-o-s velocities are shown from four of the Southern Hemisphere radars from 10:00 to 17:00 UT; Syowa East (beam 5), Syowa (beam 8), Sanae (beam 12) and Tiger (beam 5). Time intervals A and B are indicated by the red vertical dashed lines.

velocities presented in Fig, 4 demonstrate that the radars all observe strong flows moving away from the radar. There is indication that this plasma flow is pulsed. The Tiger radar is located on the nightside during this interval. The radar observes little backscatter for the majority of interval A, although the radar starts to observe strong flows towards the radar at the end of the interval.

The 1-o-s velocities from all the SuperDARN radars were combined to produce global convection maps of plasma convection for both the Northern and the Southern hemispheres for intervals $\mathrm{A}$ and $\mathrm{B}$, using the map-potential technique (Ruohoniemi and Baker, 1998). Figure 6a presents mappotential flow vectors and fitted equipotential streamlines in the Northern Hemisphere for the interval 13:28 to 13:30 UT, giving a snap-shot of the Northern Hemisphere convection pattern during interval $\mathrm{A}$. The vectors are presented as a function of magnetic local time and magnetic latitude, with 12 MLT located at the top of the plot, and dusk to the left. The velocity of the fitted vectors is coded both in colour (blue indicating the slowest velocities, red the fastest) and in the length of the vectors. The flow pattern is a standard two-cell convection pattern with anti-sunward flow over the polar cap and sunward return flow at lower latitude. The dusk flow cell dominates the dawn flow cell, with significant flow of dusk sector plasma across the noon meridian. This type of convection pattern is similar to southward IMF intervals, when magnetosheath field lines reconnect with closed magnetopsheric field lines at the dayside magnetopause (Dungey, 1963). We believe that the large IMF $\mathrm{B}_{y}$ component during interval $\mathrm{A}$ is creating a magnetic shear at the dayside magnetopause sufficient for "low-latitude" reconnection to occur, although a lobe cell may also be present as discussed further below. We note that previous studies have indicated that "low-latitude" reconnection and open flux production may not switch off entirely until the clock angle falls below $\sim 30^{\circ}$ (Sandholt et al., 1998; Grocott et al., 2003)

Figure $6 \mathrm{~b}$ presents the map-potential flow vectors in the Southern Hemisphere for the same time interval. Again 12 MLT is at the top of the page, and dusk is to the left. The flow pattern is very similar to the Northern Hemisphere flow pattern for this time interval, a standard two-cell convection pattern with anti-sunward flow at high-latitude and sunward flow at lower latitude. It appears that in the Southern Hemisphere the post-noon convection cell is also dominating the pre-noon cell. However, we do not feel confident to discuss dawn-dusk distortions of the Southern Hemisphere flow pattern, since a lack of data points, especially in the dawn and pre-noon regions, precludes us from making such comparisons. This lack of data points could also result in the mappotential flow contours being more dependent on the statistical model to which the flow vectors are fitted, rather than to actual geophysical observations. It is, nevertheless, striking that a well-developed anti-sunward flow is present in the midnight sector, indicative of on-going Dungey-cycle convection. 

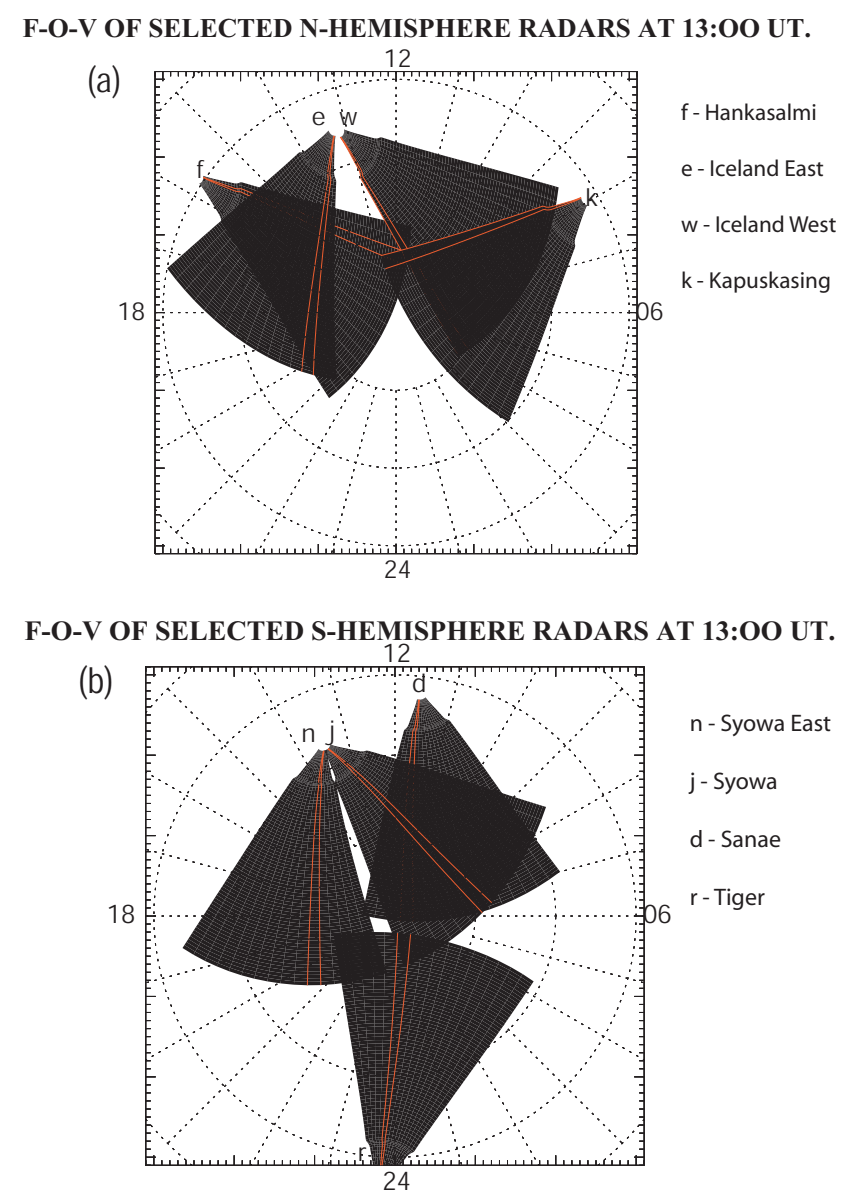

Fig. 5. The f-o-vs of the selected Northern (Fig. 5a) and Southern (Fig. 5b) SuperDARN radars are shown at 13:00 UT. The plots are in a MLAT/MLT co-ordinate system with 12:00 MLT being located at the top of the plots.

Low altitude particle precipitation data for this interval is provided by the DMSP F13 spacecraft. Figure 7 presents the spectrogram from the F13 spacecraft for the time interval 13:25 to 13:41 UT, with both ion and electron data being shown. This spacecraft pass occurred during interval A and is contemporaneous with the SuperDARN data presented in Fig. 6. The spacecraft pass was in the Northern Hemisphere, and flew through the fields of view of the Hankasalmi and Iceland East radars. Overplotted dashed lines mark the boundaries between different plasma regions. The spacecraft is first located on closed field lines in the dusk sector, demonstrated by the high energies of the precipitating ions and electrons. At 13:27:33 UT the spacecraft crosses into a region we have labelled as the "low-latitude boundary layer" (llbl), where the energy of the precipitating electrons decreases, and the spacecraft observes clear evidence of electron acceleration. At 13:28:38 UT the energy of the precipitating ions also significantly decreases, such that we judge the spacecraft to be now located on open field lines. The energy of the precipitating particles in this region is similar to that observed by Eriksson et al. $(2002,2003)$ on sunward flow within a

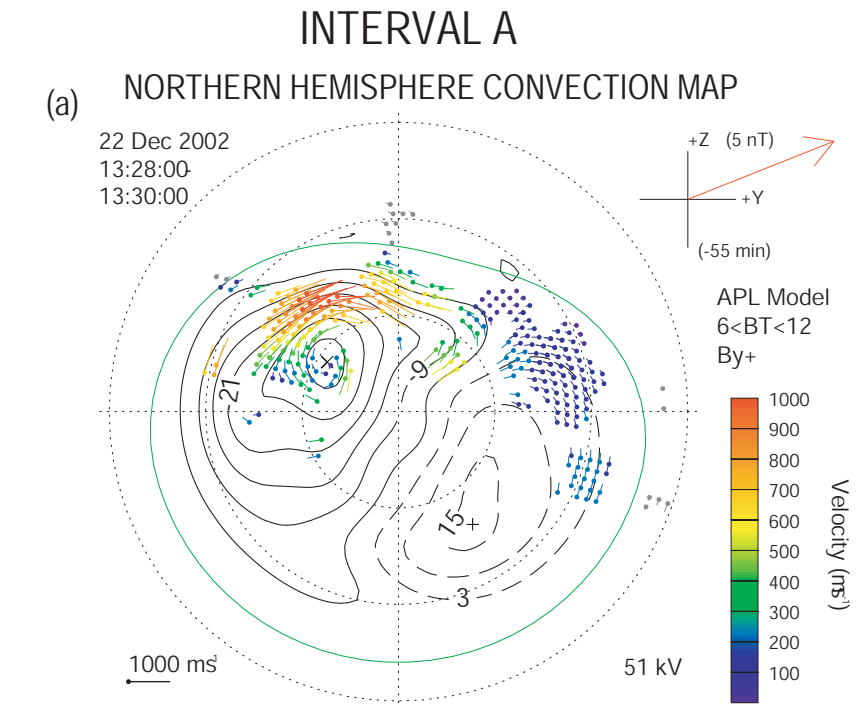

(b)
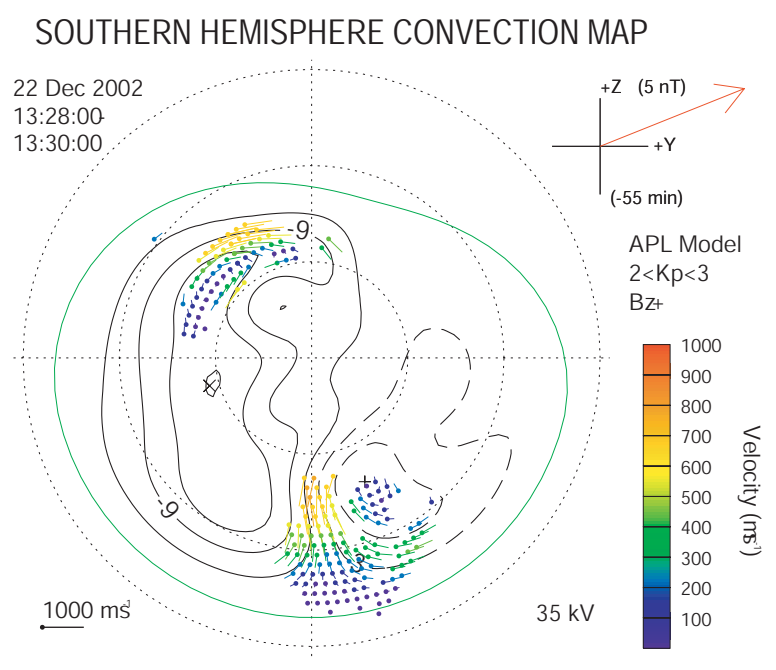

Fig. 6. (a)Shows map-potential flow vectors and equipotential streamlines observed by the Northern Hemisphere radars during the interval $13: 28$ to $13: 30 \mathrm{UT}$. The vectors are presented as a function of magnetic local time and magnetic latitude, with noon at the top and dusk to the left. The velocity of the fitted vectors is coded both in colour (blue indicating the slowest velocities, red the fastest) and in the length of the vectors. The red arrow in the top left-hand corner shows the IMF clock angle at 13:28 UT. (b) Shows mappotential flow vectors and equipotential flow streamlines observed by the Southern Hemisphere radars in the same interval, in the same format. Noon is again at the top of the plot, and dusk to the left.

lobe cell, the precipitation being associated with a transpolar auroral arc. Lyons et al. (1996) also observed precipitating electrons with similar energies in a region of negative electric field divergence in the centre of a circular convection cell (i.e. a region of clockwise flow as viewed from above the Northern Hemisphere as in the present case), which the authors identified as being associated with a polar-cap arc.

The spacecraft remains within the polar-cap arc region until 13:31:25 UT, although it does observe two narrow void regions during this time. Between 13:31:25 UT and 


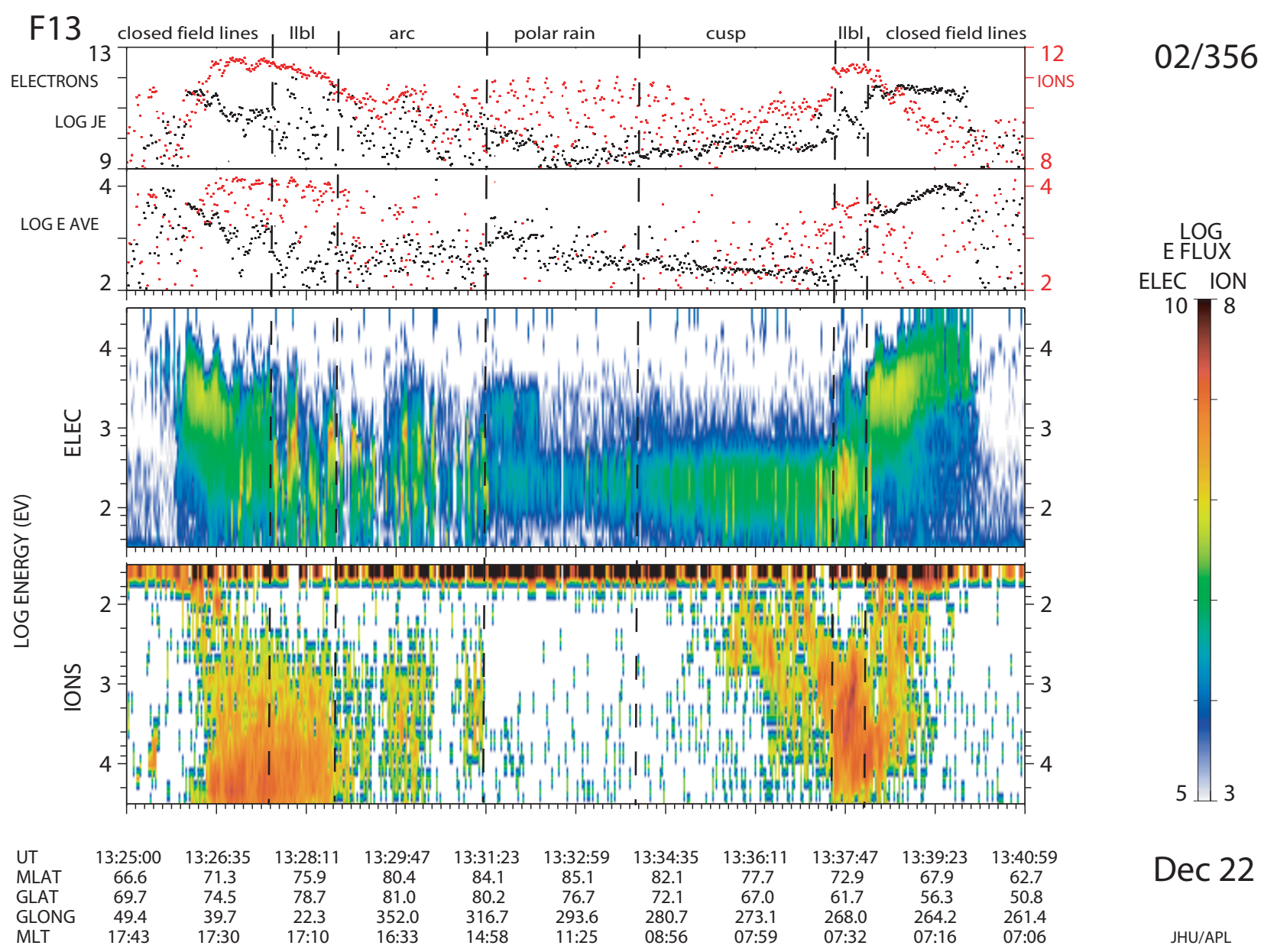

Fig. 7. Spectrogram from the DMSP F13 spacecraft for the time interval 13:25 to 13:41 UT. The black dashed lines on the plot mark the boundaries between plasma regions.

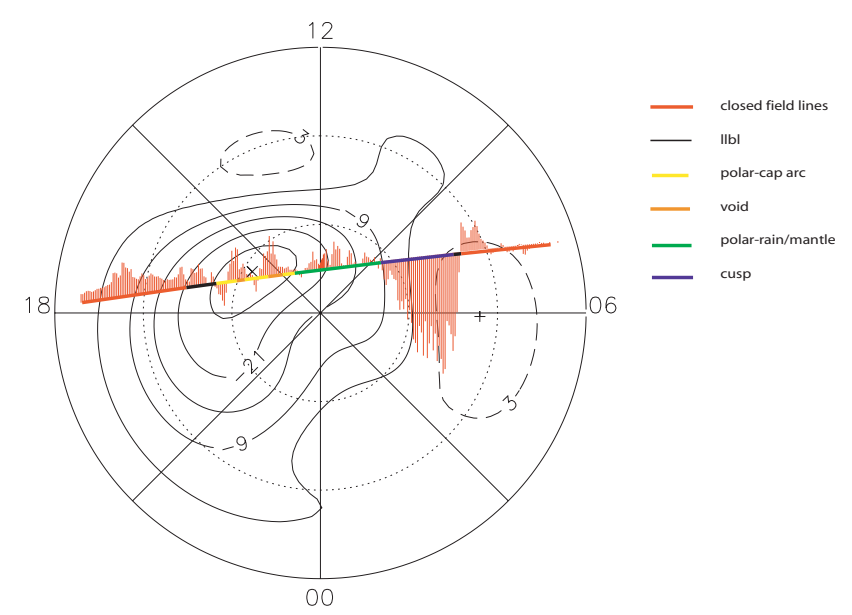

Fig. 8. The map-potential flow contours for the interval 13:34 to 13:36 UT, overlaid is the track of the F13 spacecraft from 13:24 to 13:41 UT. The track is colour coded to show the different plasma regions. Overlaid are the cross-track plasma velocity vectors measured by the DMSP spacecraft.
13:34:03 UT the spacecraft is then located within a polar rain/mantle precipitation region. At 13:34:03 UT it enters a region of cusp-like precipitation. Compared with the polar cap/mantle region, the cusp region is characterised by an enhanced flux of precipitating electrons with energies below $1 \mathrm{keV}$, as well as low-energy ions towards its lower-latitude boundary. Between 13:37:16 and 13:38:12 UT the spacecraft is again located within the llbl region, before moving on to the dawn closed field line region at 13:38:12 UT.

Figure 8 presents the map-potential flow streamlines for the interval 13:34 to 13:36 UT, overlain on which is the track of the F13 spacecraft from 13:24 to 13:41 UT. Red portions of the track indicate closed field lines, black the llbl, yellow the polar-cap arc regions, orange the void regions, green the polar-cap/mantle region, and blue the cusp. The spacecraft traverses the Northern Hemisphere polar cap from dusk to dawn. The spacecraft is initially located on closed field lines, within the sunward flow of the dusk convection cell. It then passes briefly through the llbl region, also in the region of sunward flow, before entering the polar-cap arc region, which is located at the centre of the dusk convection cell. The spacecraft then passes through the polar- 


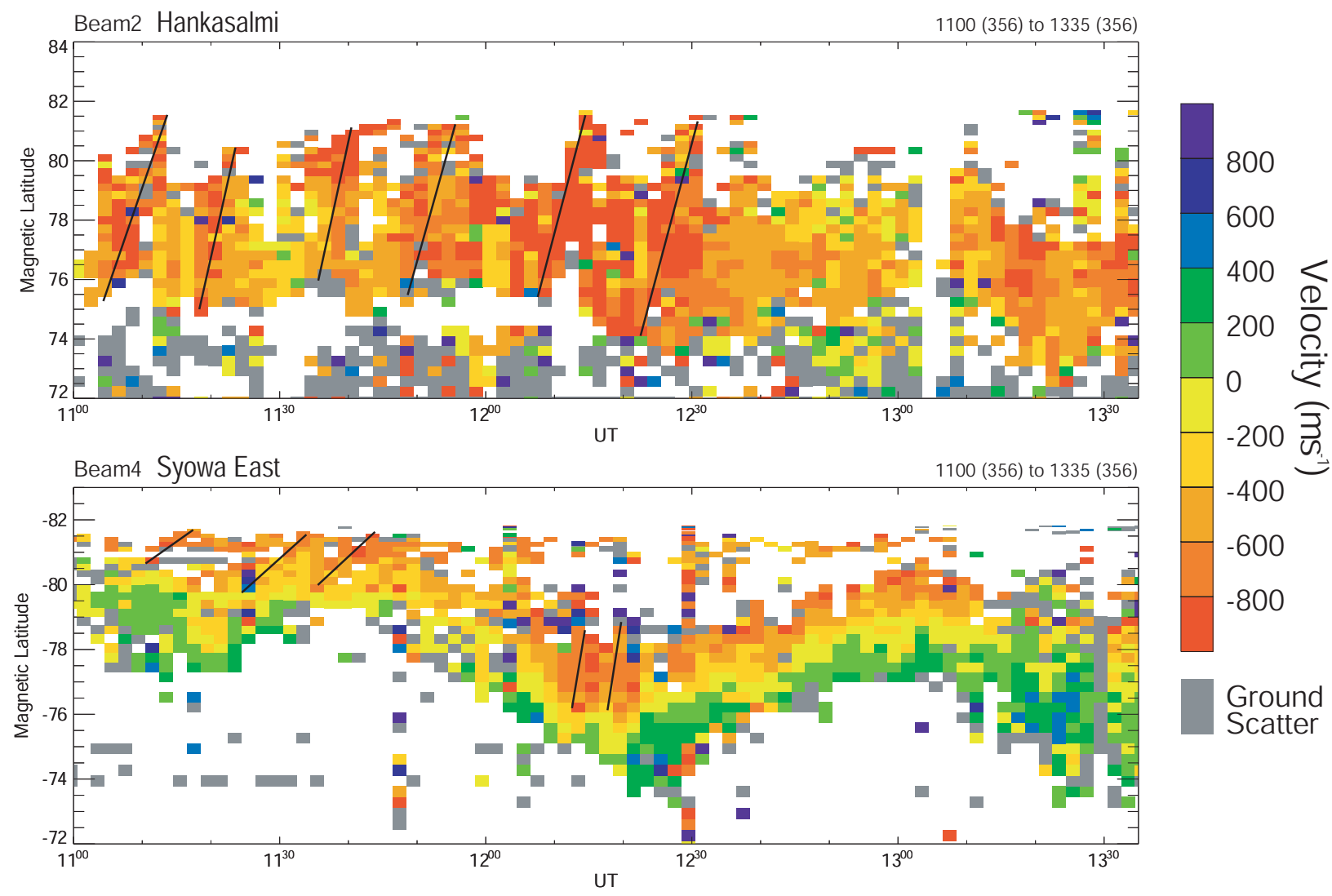

Fig. 9. L-o-s velocities from the Hankasalmi (beam 2) and Syowa East (beam 4) radars from 11:00 to 13:35 UT during interval A. Overplotted black lines highlight some of the PIFs.

rain/mantle region before entering the cusp region, located within the high-latitude convection throat in the morning sector. The spacecraft then briefly passes through the llbl region again before moving onto closed field lines which generally coincide with the sunward flows of the dawn convection cell.

Also shown in Fig. 8 are the cross-track plasma velocity vectors measured by the DMSP spacecraft. These are in general accord with the SuperDARN flow map, though some small-scale features are observed in the spacecraft data in the dusk sector, as will be discussed further below in Sect. 4, that are not reproduced in the large-scale radar map. In addition it will be noted that there is a discrepancy in the sense of the cross-track flow in the noon sector, with the radar-derived map indicating an antisunward flow in this region, while the spacecraft data indicate a weak sunward flow. We note, however, that radar backscatter is not actually observed in this specific region during the interval (see Fig. 6a) with the implication that the streamlines of the "dusk" cell are actually more extended across noon into the dawn sector than is implied by the radar map. The principal flow at the spacecraft was thus most probably a flow along the track from dusk-todawn.

Figure 9 presents the 1-o-s velocity observed in beam 2 of the Hankasalmi radar and beam 4 of the Syowa East radar during interval A. The Hankasalmi and Syowa East radars view approximately conjugate regions of the ionosphere but with different viewing direction to the flow. The Hanksalmi radar is clearly observing pulsed ionospheric flows (PIFs) moving away from the radar at high latitude. The PIFs have a recurrence rate of approximately $15 \mathrm{~min}$. Some of the PIFs have been identified on Fig. 9 with black lines, in order to guide the eye. Previous work by Provan et al. (1998) has identified PIFs as being the ionospheric signature of FTEs occurring at the dayside magnetopause. The Syowa East radar is observing a flow reversal boundary with the plasma flowing towards the radar equatorwards of the boundary and away from the radar polewards of the boundary. Syowa East also appears to be observing pulsed flows at this time, poleward of the flow reversal boundary. A few of these flows have been tentatively identified with black lines. However, the pulsed flow signatures in the Southern Hemisphere plot are not as clear and easy to identify as the pulsed signatures observed in the Northern Hemisphere.

In order to further examine the pulsed flow, we selected a few range gates within the main regions of backscatter identified in Fig. 9, and present the averaged 1-o-s velocity from these ranges in Fig. 10. The top panel shows the average 1-o$\mathrm{s}$ velocity observed at six ranges between magnetic latitude $76^{\circ}$ to $80^{\circ}$ for beam 2 of the Hanksalmi radar. The bottom panel shows the averaged velocity observed at eleven ranges 

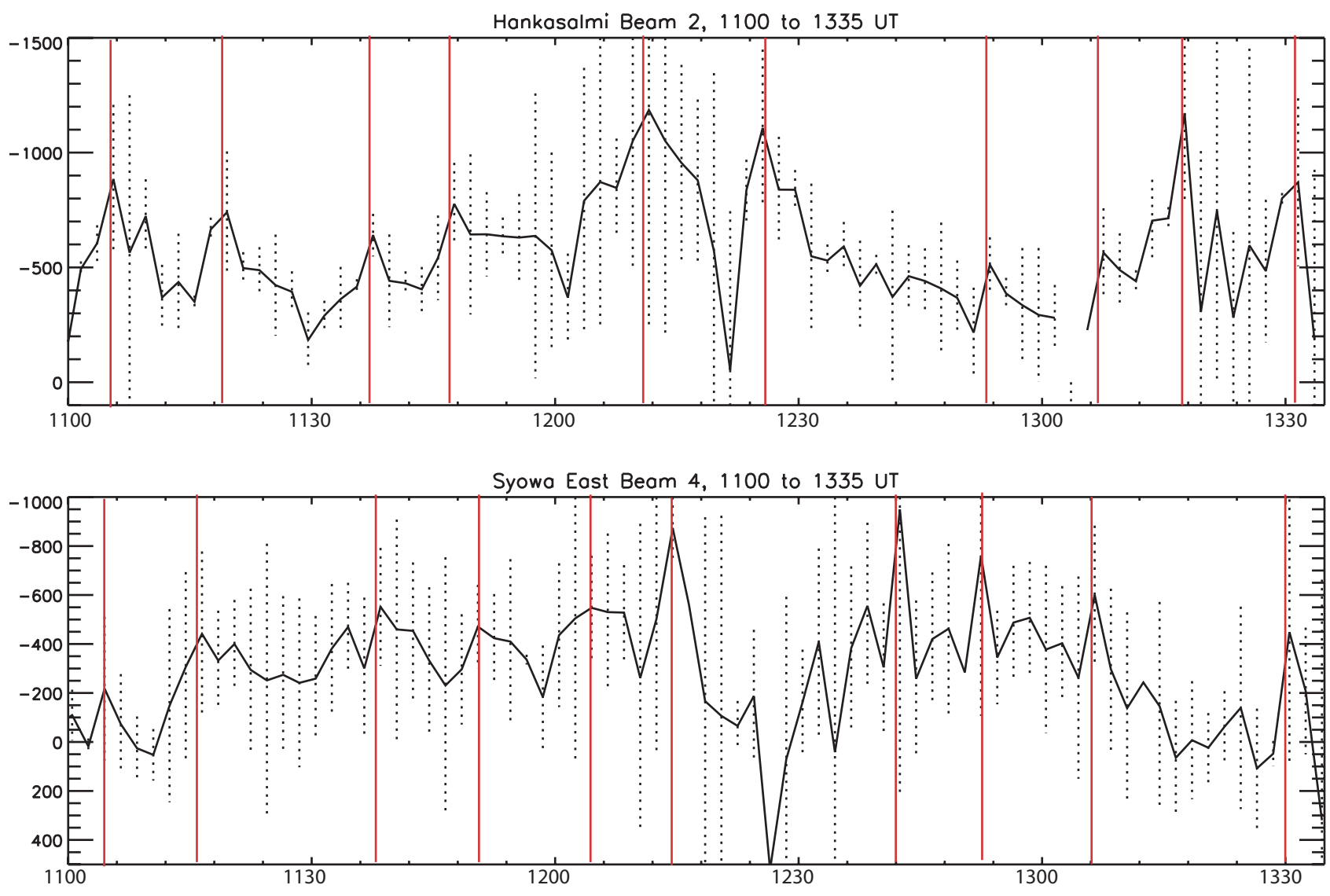

Fig. 10. The top panel presents the average l-o-s velocity observed at six ranges between magnetic latitude $76^{\circ}$ to $80^{\circ}$ for beam 2 of the Hanksalmi radar. The bottom panel shows the averaged velocity observed at selected ranges between latitudes $-76^{\circ}$ to $-82^{\circ}$ for beam 4 of the Syowa East radar. The dashed black lines are the standard deviation of the average velocity. Solid red lines highlight selected flow pulses.

between latitiudes $-76^{\circ}$ to $-82^{\circ}$ for beam 4 of the Syowa East radar. The dashed black lines presented on the graphs are the standard deviation of the average velocity. Figure 10 clearly demonstrates that flow pulses are observed in both hemispheres, as marked by the solid red lines, with the magnitude of the 1-o-s velocities fluctuating with time. These PIFs have an average recurrence period of $\sim 15 \mathrm{~min}$ in both the Northern and Southern Hemispheres.

FTEs at the dayside magnetopause result in the addition of open flux to the polar-cap and the subsequent equatorward motion of the polar cap boundary. Previous work by Milan et al. (1998) demonstrated that the latitudinal extent of the ionospheric backscatter in the dayside auroral regions relates to the boundaries of geophysical processes. Specifically, Rodger et al. (1995) and Milan et al. (1999) identified the equatorward boundary of the radar backscatter near noon to be co-located with the equatorward boundary of $630 \mathrm{~nm}$ emission from cusp precipitation. Although the open-closed field line boundary (OCB) may be typically displaced a few tens of $\mathrm{km}$ equatorward of the boundary of the emission, we can thus nevertheless use the backscatter boundary to track the motion of the OCB poleward or equatorward. The equatorward edge of the radar backscatter for the interval studied here has been determined from the Northern Hemisphere map-potential global convection plots. Figure 11 presents the position of the equatorward boundary of radar backscatter from 11:30 to 13:30 UT during interval A. The position of the boundary is quantised by the map-potential grid to which the vectors are mapped, which has grid cells which are $1^{\circ}$ in latitude $(\sim 111 \mathrm{~km}$ projected onto the Earth's surface), and as close to $111 \mathrm{~km}$ in longitude as possible. The equatorward boundary of radar backscatter is at a latitude of $78.5^{\circ}$ at 11:30 UT, but by 13:30 UT the boundary has moved equatoward to a latitude of $69.5^{\circ}$. This equatorward progression of the radar backscatter is not gradual and continuous, but stepwise, with an equatorward "step" of the boundary approximately every 15 min. However, between $\sim 12: 15$ and $\sim 12: 35$ UT the radar backscatter boundary moved in a mainly poleward direction, at this time the IMF $\mathrm{B}_{z}$ component was generally equal to or greater than the $\mathrm{B}_{y}$ component.

\subsection{Interval B}

We have defined interval $B$ as lasting from 13:35 to 16:10 UT. During this time the IMF $\mathrm{B}_{z}$ component was generally larger the $\mathrm{B}_{y}$ component, except for a few minutes around 14:20 UT when the IMF $\mathrm{B}_{y}$ component became strongly neg- 
ative resulting in a clock angle of $\sim-60^{\circ}$. Between 14:30 and 16:10 UT the IMF conditions were fairly steady with the IMF $\mathrm{B}_{z}$ component dominating the $\mathrm{B}_{y}$ component.

Studying Figs. 3 and 4, we can see that there is a rapid and extensive reconfiguration in the plasma flow observed by the SuperDARN radars between interval A and interval B. The IMF $\mathrm{B}_{z}$ component starts to dominate $\mathrm{B}_{y}$ at 13:35 UT. For the next ten minutes or so the plasma flow appears unchanged with the Hankasalmi and Iceland West radars continuing to observe strong flows away from the radar and the Iceland East radar continuing to observe strong flows towards the radar. Between $\sim 13: 50$ and $\sim$ 14:00 UT these three dayside Northern Hemisphere radars all observe a decrease in 1-o-s velocity. This may be related to the changing direction of the IMF $B_{y}$ component at 13:50 UT. At $\sim 14: 00$ UT the Iceland West and Iceland East radars both start to observe strong flows, directed in the opposite direction to the flows observed prior to $\sim 13: 50$ UT.

Figure 12 presents Northern Hemisphere map-potential flow vectors and equipotential streamlines for the interval 14:02 to 14:04 UT. A four cell flow pattern is observed, as opposed to the two-cell pattern detected during interval A. The two high-latitude cells are "reverse" convection cells with sunward flow over the polar-cap and anti-sunward flow at lower latitude, with the post-noon cell being stronger than the pre-noon cell. The plasma flow in the two lower latitude cells are rotating in the "standard" direction with antisunward flow at high-latitude. The overall flow pattern is typical of flows observed during northward IMF when lobe merging is occurring (e.g. Burke et al., 1979; Knipp et al., 1991; Freeman et al., 1993).

The multi-cell flow pattern shown in Fig. 12 is the first four cell flow pattern to be observed by the radars during interval B. Thus it takes $\sim 25$ min from when the IMF $B_{z}$ component starts to dominate the $\mathrm{B}_{y}$ component, until the first four cell flow pattern is observed. In the transitional period between 13:35 and 14:02 UT the ionospheric flow pattern is very variable, with highly distorted two cell patterns, and some three cell patterns, being observed. This dynamic high-latitude convection is observed as the global convection reconfigures from a standard convection pattern to a reverse convection pattern, however it will also be influenced by the variable magnetic field conditions observed during this time.

After 14:30 UT the magnetic field conditions become more stable with the $\mathrm{B}_{z}$ component dominating the $\mathrm{B}_{y}$ component. Figure 13 presents the Northern Hemisphere mappotential flow vectors and equipotential streamlines observed at three times during interval $\mathrm{B}$; for 2 min intervals starting at (a) 15:00 UT, (b) 15:08 UT and (c) 15:26 UT. The reasons for selecting these specific times will be explained later in this section. Again, four convection cells are observed during each interval. Due to the lack of backscatter in the Southern Hemisphere during interval B, we are unable to present a similar analysis of the Southern Hemisphere flows.

Figure 14 presents data from the DMSP F13 spacecraft for the time interval 15:06:00 to 15:20 UT. At 15:06 UT the F13 DMSP spacecraft is located at a MLAT of $64.8^{\circ}$ and a

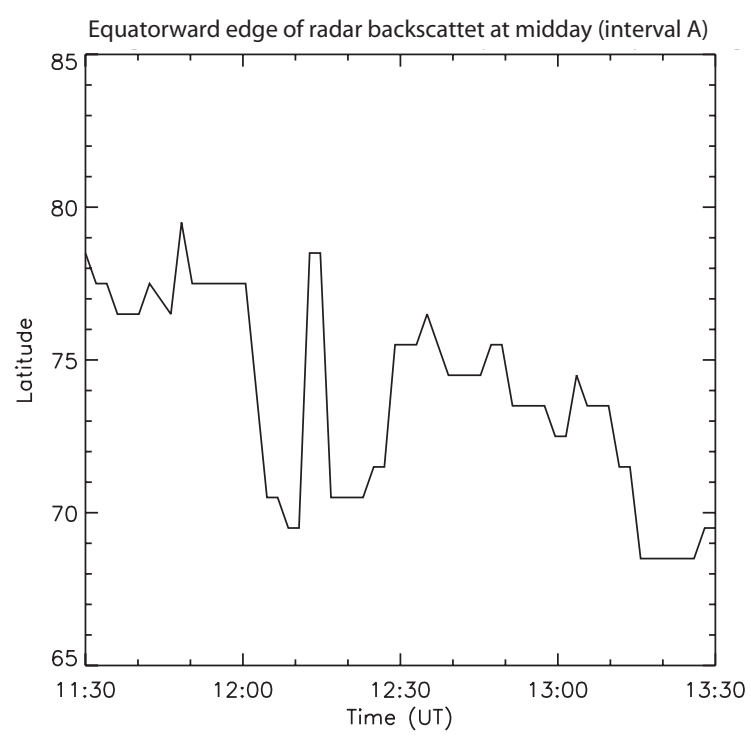

Fig. 11. The latitudinal position of the equatorward boundary of radar backscatter at local magnetic noon, observed between 11:30 and 13:30 UT during interval A.

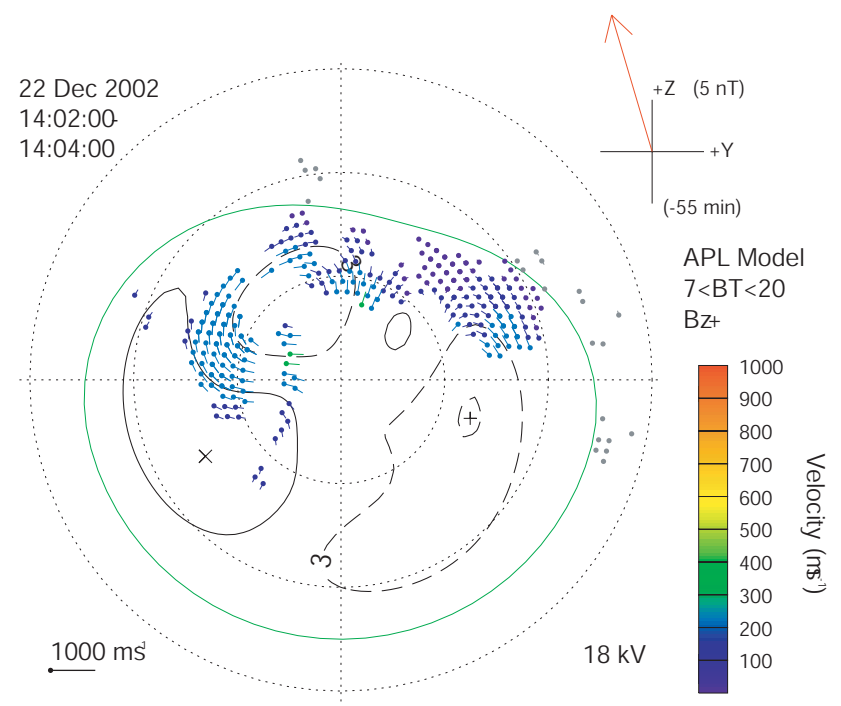

Fig. 12. The Northern Hemisphere map-potential flow vectors and equipotential flow streamlines observed between 14:02 and 14:04 UT (interval B).

MLT of 17:57. Over the next fourteen minutes the spacecraft traverses the polar cap, and at 15:20 UT it is located in the dawn sector at 06:36 MLT and 68.3 $3^{\circ}$ MLAT. The spacecraft identifies a decline in ion energy, indicative of the dusk side OCB, at a magnetic latitude of $\sim 79.1^{\circ}$ and 17:38 MLT, and similarly at $\sim 78.5^{\circ}$ MLAT and 06:53 MLT. These times are marked with dashed vertical black lines on the plot. A detailed analysis of the high-latitude particle precipitation observed poleward of the two OCBs is outside the scope of this paper, and will be presented in a subsequent paper. 
(a)

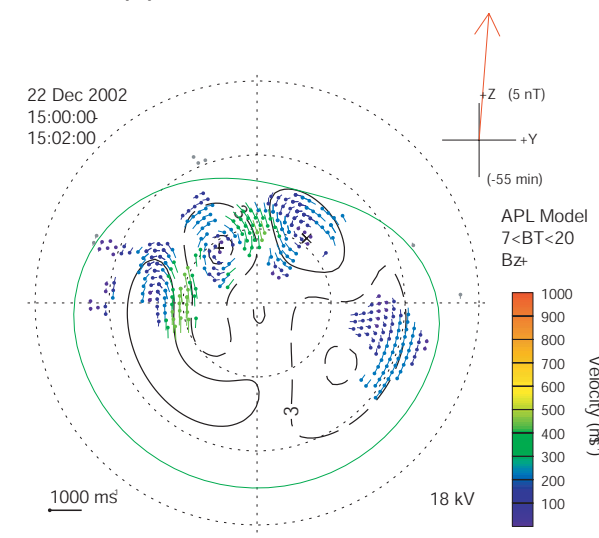

(b)

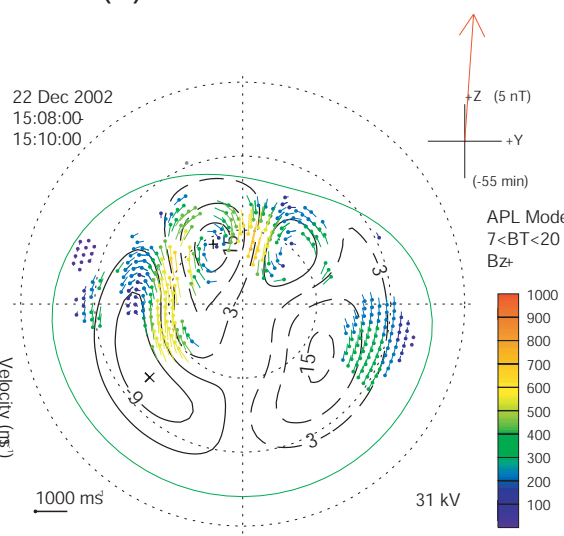

(c)

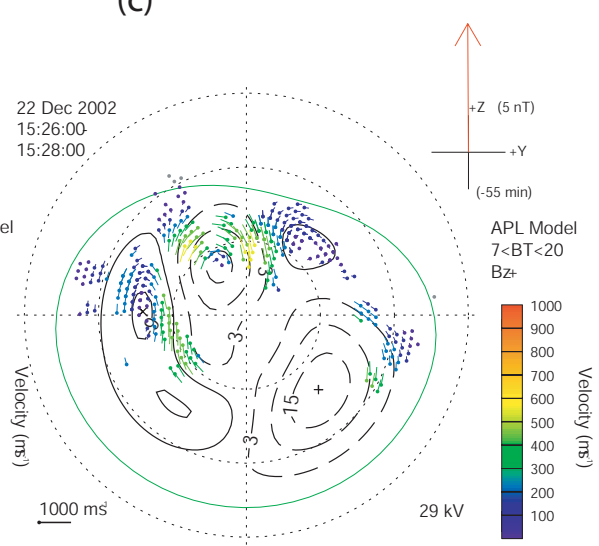

Fig. 13. The Northern Hemisphere map-potential flow vectors and equipotential flow streamlines observed at two minute intervals starting at: (a) 15:00 UT, (b) 15:08 UT and (c) 15:26 UT.

Figure 15 presents a polar-plot of the DMSP F13 spacecraft track across the Northern Hemisphere polar region from 15:06 to 15:20 UT. The track is presented as a function of MLAT and MLT, with local noon being located at the top of the plot. The track of the spacecraft is coloured blue equatorward of the open-closed field line boundary, and red poleward of the open-closed field line boundary. Overlaid on the plot are the potential contours observed by the map-potential technique from 15:08 to 15:10 UT (previously presented in Fig. 11). From the figure it can be seen that the two OCB identified in Fig. 14 are located near the poleward boundary of the low-latitude dawn and dusk cells, such that the lowlatitude dawn and dusk cells are located on closed field lines.

In the previous section we demonstrated that pulsed flows were observed during interval $\mathrm{A}$. As stated above pulsed flows are also observed during interval B, which we will now study in more detail. Figure 16 presents the 1-o-s velocity vectors observed by beam 15 of the Kapuskasing radar and beam 2 of the Iceland East radar from 13:50 to 16:10 UT during interval B. Beam 15 of the Kapuskasing radar is observing the cusp region at this time, and observes flow towards the radar. Before $\sim 14: 30$ UT the observed 1-o-s velocity is comparatively small, after 14:30 UT the 1-o-s velocity increases significantly. There also appears to be a decline in radar backscatter for a few minutes at $\sim 14: 25$ UT. This decline, and the subsequent increase in the observed 1-o-s velocity, is probably due to the variable IMF conditions during $\sim 14: 20$ to $\sim 14: 30$ UT. The IMF $B_{z}$ component dominated the $\mathrm{B}_{y}$ component for most of interval $\mathrm{B}$, expect for a few minutes around $\sim 14: 20$ UT. After 14:30 UT the magnetic field conditions remained relatively stable, with the IMF $\mathrm{B}_{z}$ component significantly larger than the $\mathrm{B}_{y}$ component. Five clear flow bursts are observed during interval $\mathrm{B}$, these pulses being marked with overplotted black dashed lines. As the fluctuating IMF conditions before 14:30 UT may affect the flow pulsations, and the occurrence of radar backscatter, we concentrate on the flows observed after 14:30 UT when the IMF conditions were relatively stable. Four pulses are ob- served between $\sim 14: 30$ and $\sim 16: 00$ UT, thus having a periodicity of approximately 25 min. Beam 2 of the Iceland East radar is located in the post-noon sector at this time, and is pointing in an azimuthal direction, observing the dusk sector. The radar observes strong pulsed flow away from the radar. Due to the zonal pointing direction of the radar beam these pulses can be more difficult to identify in the Iceland East data as compared with the Kapuskasing radar. The approximate position of five pulses observed by the Iceland East radar is marked on the bottom panel of Figure 16 with overplotted black lines.

We wish to study the global flow patterns during the pulsed flows in more detail. Superimposed on the Kapuskasing 1o-s velocity presented in Fig. 16 are three red arrows labeled (a), (b), and (c). Arrow (a) is positioned just before a flow burst at 15:00 UT, arrow (b) is positioned in the middle of a flow burst at 15:08 UT and arrow (c) just after the flow burst at 15:26 UT. The map-potential flow patterns from these times have already been presented in Fig. 13, and labelled (a), (b), and (c). At all times multi-cell flow patterns are observed with the high-latitude post-noon flow cell dominating the high-latitude pre-noon flow cells. At time (a) relatively low velocity flows are observed by the radars. At time (b) much stronger velocity flows are observed by the Northern Hemisphere radars. This increase in the strength and magnitude of the plasma flow is particularly evident in the high-latitude post-noon flow cell with increased flow observed from 11:00 MLT to 21:00 MLT. At time (c) (after the flow burst) the magnitude of the plasma flow has again decreased.

In order to analyse whether these bursts of lobe reconnection were affecting the amount of open flux within the polar cap, we again used the equatorward boundary of radar backscatter at magnetic noon to track the position of the OCB. As in interval A, the equatorward edge of the radar backscatter was determined from the Northern Hemisphere map-potential global convection maps. Figure 17 presents the latitude of the equatorward edge of the radar backscat- 


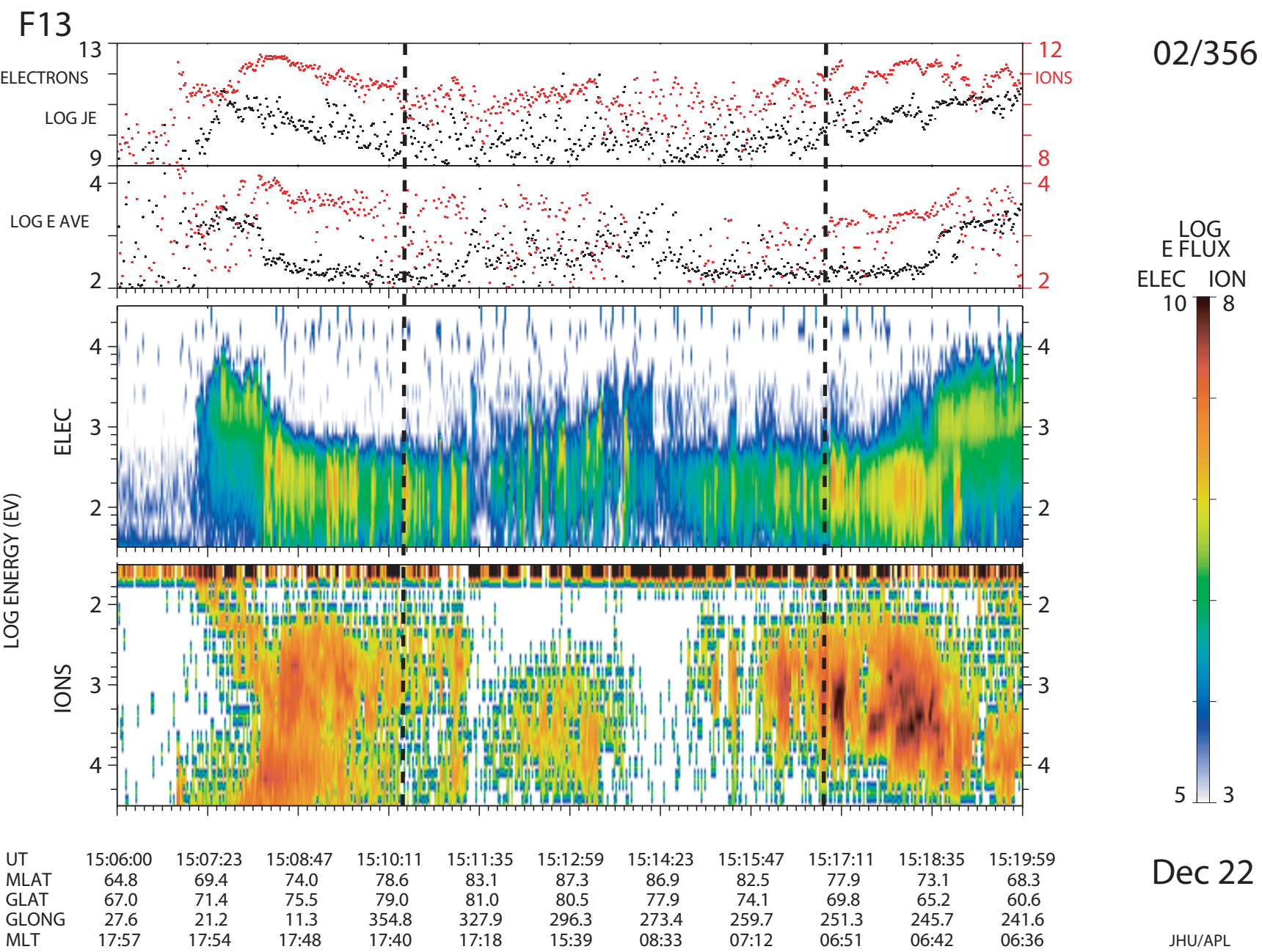

Fig. 14. Spectrogram from the DMSP F13 spacecraft for the time interval 15:06 to 15:20 UT. The two black dashed lines on the plot indicate boundaries between open and closed field lines.

ter at magnetic local noon between 14:30 UT and 16:10 UT. This period was chosen as the IMF was particularly stable during this time. The radar backscatter boundary was at a latitude of $74.5^{\circ}$ at $14: 30 \mathrm{UT}$, but by $16: 10 \mathrm{UT}$ it had moved poleward to a latitude of $76.5^{\circ}$. This poleward motion of the boundary was not steady, but occurred in a stepwise manner. Between 14:30 and 16:10 there were five poleward retractions of the boundary, with the boundary relaxing slightly equatorward between each of these retractions. Thus, there was an average time period $\sim 23$ min between each poleward retraction of the radar backscatter, similar to the repetition rate of the bursts of lobe reconnection. Our observations are consistent with the closure of open flux at the dayside magnetopause during these bursts of lobe reconnection, resulting in the stepwise retraction of the OCB.

\section{Discussion}

We have performed a detailed case study of one interval of prolonged northward IMF, which occurred on 22 December
2002. We have utilised data from the Northern and Southern Hemisphere SuperDARN radars, the low-altitude F13 DMSP spacecraft, the ACE spacecraft, as well as the map-potential analysis tool. We have studied two intervals during this day in particular detail. During interval A (11:00 to 13:35 UT) the IMF $\mathrm{B}_{y}$ component was positive and comparable with or greater in magnitude than the IMF $\mathrm{B}_{z}$ component. During interval $\mathrm{B}(13: 35$ to $16: 10 \mathrm{UT})$, the IMF $\mathrm{B}_{z}$ component was predominantly greater than the $\mathrm{B}_{y}$ component (except for a few minutes around 14:20 UT). This change in the IMF conditions corresponded to a significant change in the highlatitude convection pattern.

We have presented map-potential global convection patterns for both the northern and Southern Hemisphere. The convection patterns are calculated by a mathematical fitting technique using all the available line-of-sight velocity measurements. The solution is constrained by folding in information from a statistical model (Ruohoniemi and Greenwald, 1996), keyed to the IMF conditions. As the 1-o-s vectors are fitted to a model, it is always useful to investigate how im- 


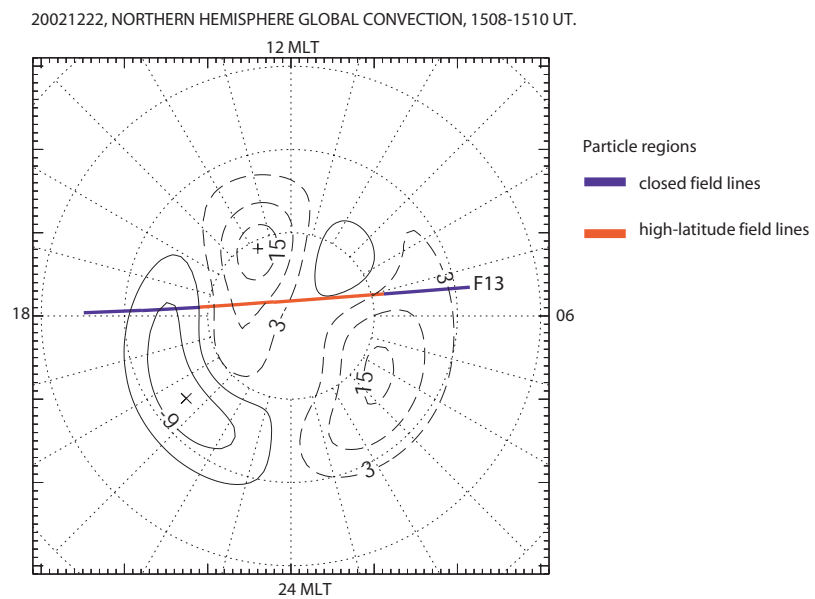

Fig. 15. Polar-plot of the DMSP F13 spacecraft track across the Northern Hemisphere polar region from 15:06 to 15:20 UT. The track is presented as a function of MLAT and MLT, with local noon being located at the top of the plot. The track of the spacecraft is coloured blue equatorward of the open-closed field line boundary, and red poleward of the open-closed field line boundary. Overlaid on the plot are the potential contours observed by the map-potential technique from 15:08 to $15: 10 \mathrm{UT}$

portant the model is in determining the final convection pattern. Since the model is parameterised by the upstream IMF, a good way to check its influence is to force the model to use a fixed IMF input with different characteristics to those actually observed (e.g. Grocott et al., 2002). For the present study we reanalysed our northward IMF interval with the IMF input fixed in a strong southerly orientation with an opposite sense of $\mathrm{B}_{y}$. The results, while sometimes different in regions of little or no radar backscatter, showed similar flow patterns in regions where radar data were present. Indeed, evidence of lobe "reverse" convection cells was still clearly apparent, even though the statistical model for southward IMF conditions contains no such cells. This illustrates that, in the present case, the data are clearly dominating the model in our determination of the convection pattern and gives us confidence in using these pattern to draw conclusions on the nature of the flow.

During interval A both the Northern and Southern Hemisphere map-potential flow contours showed a distorted twin cell convection pattern with anti-sunward flow at highlatitude, and sunward return flow at lower latitude (Figs. 6a and b). The Northern Hemisphere flow pattern is distorted with the dusk flow cell dominating the dawn cell, and significant flow of dusk sector plasma across the noon meridian. The Southern Hemisphere radars also observed a two-cell convection pattern (Fig. 6b). It would appear from the derived convection pattern that in the Southern Hemisphere the post-noon convection cell is dominating the pre-noon cell. However, we do not feel confident in discussing potential distortion in the Southern Hemisphere flow pattern, due to the lack of data in the dawn and pre-noon regions. The presence of antisunward flow in the midnight sector, however, is consistent with the continuous presence of Dungey cycle convection.

Heppner and Maynard (1987) presented Northern Hemisphere empirical flow patterns for intervals of positive IMF $\mathrm{B}_{y}$. The distorted two-cell convection pattern observed by Heppner and Maynard (1987) under weakly positive IMF $\mathrm{B}_{z}$ conditions are similar to the Northern Hemisphere flow pattern presented in Fig. 6a. The flow pattern shows the typical $\mathrm{B}_{y}$ asymmetry that one would expect for standard Dungey-cell flow, as has previously been discussed by e.g. Jørgensen et al. (1972) and Cowley (1981). It is interesting to note that this $\mathrm{B}_{y}$ flow asymmetry persists when the clock angle is $\sim 50^{\circ}$ to $\sim 60^{\circ}$. Grocott et al. (2003) has observed a highly distorted $\mathrm{B}_{y}$ dominated twin cell flow pattern when the IMF clock angle was $\sim-50^{\circ}$ to $\sim-60^{\circ}$. Our results support previous observations by e.g. Clauer and FriisChristensen (1988), Freeman et al. (1993) and Greenwald et al. (1995), that during intervals of positive IMF $B_{z}$ and a large IMF $\mathrm{B}_{y}$, the magnetic shear at the dayside magnetopause is sufficient for reconnection to occur equatorward of the polar cap, resulting in the creation of a distorted twocell convection pattern. Similar conclusions have also been reached from studies of the cusp auroral morphology (e.g. Sandholt et al., 1998).

However, in this study combining global convection patterns with particle precipitation observations have shown that the observed convection pattern does not just consist of two distorted merging cells. Within the centre of the dusk convection cell we observed polar cap arc particle precipitation. Such precipitation has previously been observed in a dusk convection cell during an interval of positive IMF $\mathrm{B}_{y}$ and $\mathrm{B}_{z}$ where $\mathrm{B}_{y} \gg \mathrm{B}_{z}$ (Eriksson et al., 2002, 2003). Eriksson et al. $(2002,2003)$ observed the polar cap arc particle precipitation on sunward flow within a high-latitude lobe cell in the dusk region. The lobe cell was located next to a viscous cell within the dusk merging cell. The observed convection pattern was a three-cell convection system of coexisting merging, viscous and lobe-type convection cells, as suggested by Burch et al. (1985) and Reiff and Burch (1985). During intervals of positive (negative) IMF $\mathrm{B}_{y}$ they predicted that the dusk (dawn) merging cell dominates the dawn (dusk) cell in the Northern Hemisphere, and that the lobe and viscous cells where to be found within the dusk (dawn) merging cell. Eriksson et al. (2002) found that the existence of such composite convection cells was strongly linked to conditions of IMF $\mathrm{B}_{y} / \mathrm{B}_{z}>1$. The observations presented in this paper are consistent with a large IMF $\mathrm{B}_{y}$ component creating a magnetic shear at the dayside magnetopause sufficient for reconnection to occur on closed field lines located equatorward of the OCB, simultaneously with merging in the high-latitude lobe regions.

In this study we observed a lobe convection cell within the centre of the dusk merging cell. Burch et al. (1985) suggested that equatorward of this lobe cell we should observe a narrow viscous cell. A convection reversal should then be observed within the viscous cell and a second flow reversal should be observed within the higher-latitude sunward flow cell of the 


\section{INTERVAL B}
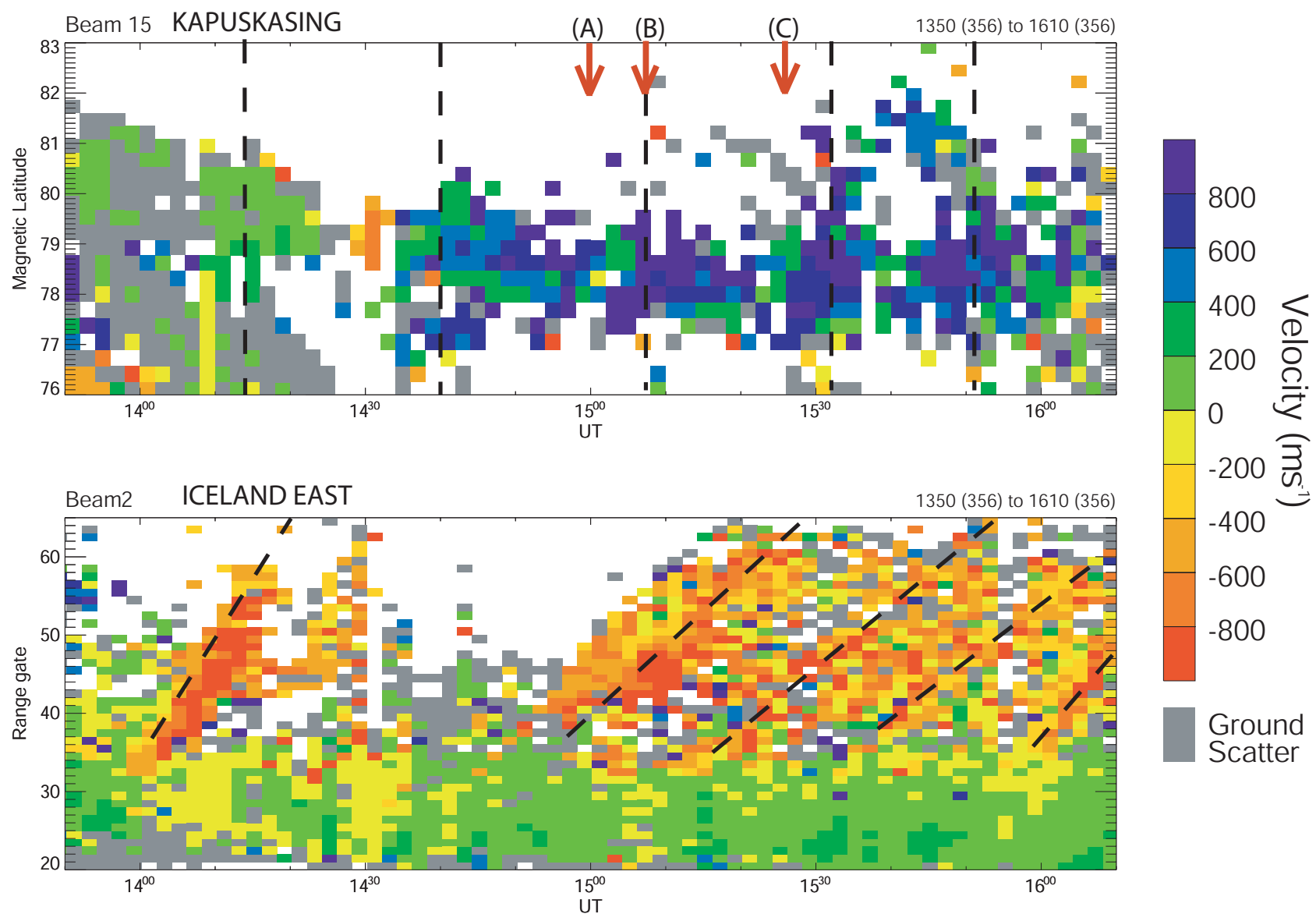

Fig. 16. The 1-o-s velocity observed by beam 15 of the Kapuskasing radar and beam 2 of the Iceland East radar from 13:50 to 16:10 UT (during interval B). Overlaid black lines highlight flow pulsations. Three red arrows are overlaid on the 1-o-s velocity observed by the Kapuskaing radar, and labelled a, b and c. Arrow a is positioned just before a flow burst at 15:00 UT, arrow b is positioned in the middle of a flow burst at 15:08 UT and arrow c just after the flow burst at 15:26 UT. The times correspond to the flow maps shown in Figs. 13a, b and c.

lobe cell and the lower-latitude anti-sunward flow of the viscous cell. The map-potential global convection pattern does not observed this anti-clockwise rotating viscous cell, however the cross-track DMSP vectors shows a narrow regions of anti-sunward flow at the equatorward edge of the lobe convection cell, consistent with the viscous convection cell predicted by Burch et al. (1985). It is possible that this narrow flow cell is not present on the map-potential global convection pattern as the map-potential technique produce global maps of the plasma flow, and small-scale flow changes may be overlooked.

The dusk lobe cell lies within polar-cap arc precipitation, as defined by Lyons et al. (1996). Eriksson et al. (2002, 2003) reported that such polar-cap arc precipitation is associated with sunward flow on high-latitude lobe cells. Our observations suggest that the polar-cap arc precipitation is associated with both the sunward and anti-sunward flow of the lobe cell. However, this result may be due to the shape of the lobe cell not being accurately reproduced by the map-potential algorithm as mentioned earlier. The lobe cell was partially within the field-of-view of the Goose Bay radar at this time, and as stated above the Goose Bay radar was not working during this interval. The DMSP flow vectors also suggest that there is a flow stagnation region within the lobe cell, with some very weak anti-sunward flow being observed. Eriksson et al. (2002) also observed a flow stagnation region within a high-latitude lobe cell, poleward of the region of sunward plasma convection. They noted that Phan et al., 2000 reported that the WIND spacecraft observed a similar region of stagnant magnetosheath-like ions deep inside the magnetotail lobes.

Reiff and Heelis (1994) have suggested that the distorted two-cell convection pattern may be a transitional pattern which occurs as the IMF conditions changes. Our results, and the results presented by Greenwald et al. (1995) and Grocott et al. (2003), would suggest that the distorted two-cell convection pattern is a stable configuration, occurring when the IMF $\mathrm{B}_{y}$ component is positive and dominates the IMF $\mathrm{B}_{z}$ component. 


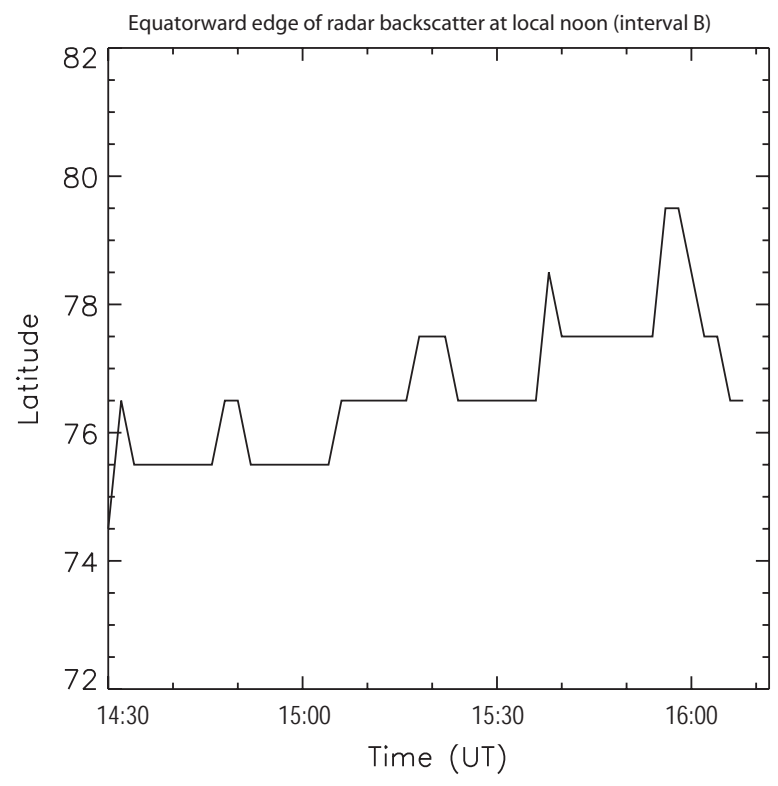

Fig. 17. The latitudinal position of the equatorward boundary of radar backscatter at local magnetic noon, observed between 14:30 and 16:10 UT during interval B.

During interval A, the Northern and Southern Hemisphere radars observed pulsed high-velocity flows moving to higher-latitudes with time, with an average recurrence rate of $\sim 15$ min (Figs. 9 and 10). This flow was observed to lie within the two merging cells, and it is not yet clear whether the flow within the dusk lobe cell was also pulsating. During interval A the equatorward edge of the Northern Hemisphere radar backscatter also moved equatorward in a stepwise manner approximately every $15 \mathrm{~min}$, suggesting that the OCB moved in a similar manner. In the past, pulsed flows have been observed on open field lines by the SuperDARN radars (Provan et al., 1998), and have been identified as being the ionospheric signatures of FTEs occurring at the dayside magnetopause. The observations presented here are consistent with flux transfer events occurring at the dayside magnetopause with a repetition rate of $\sim 15 \mathrm{~min}$. The FTEs are observed as PIFs in the radar data, and result in the bursty addition of open flux to the dayside magnetosphere and the subsequent stepwise equatoward expansion of the OCB. Previous work by Milan et al. (1999) used the equatorward boundary of the radar aurora as a proxy for the open-closed field line boundary, and related the rapid equatorward motions of this boundary to the occurrence of individual flux transfer events. Our results are the first detailed analysis of flux transfer events observed during an interval of northward IMF. However, McWilliams et al. (2000) performed a statistical study of pulsed ionospheric flows. The analysis technique was based on the Fourier transform, which was used to select the dominant repetition rates of the periodic flow bursts seen along the radar line-of-sight. One third of the pulsed ionospheric flow intervals occurred when the interplanetary magnetic field had a northward component, although the rel- ative magnitude of the $\mathrm{B}_{y}$ component was not considered by these authors.

During interval $\mathrm{B}$ the IMF $\mathrm{B}_{z}$ component was generally greater than the IMF $\mathrm{B}_{y}$ component. The 1-o-s velocities observed in the Northern (Fig. 3) and Southern (Fig. 4) Hemispheres demonstrated an extensive and dramatic reorganisation of the high-latitude plasma flows. In the Northern Hemisphere the high-latitude flow pattern changed from a standard two cell convection pattern to a reverse four cell convection pattern over a $\sim 25$ min period. However, the variable IMF conditions might have effected the time it took for the flow patterns to reorganise. Previous work by e.g. Clauer and Friis-Christensen (1988), and Freeman et al. (1993) stated that while a distorted standard two cell convection pattern could be observed during northward IMF $\mathrm{B}_{z}$ and large IMF $\mathrm{B}_{y}$ conditions, convection under a northward IMF $\mathrm{B}_{z}$ but a small IMF $\mathrm{B}_{y}$ was most consistent with a four cell convection pattern, as found here.

The Southern Hemisphere radars which observed the dayside during intervals A and B (Syowa, Syowa East and Sanae) experienced a sudden decline in radar backscatter during interval $\mathrm{B}$, as compared with interval A. However, this decline in the radar backscatter may be related to a change in the direction of the IMF $\mathrm{B}_{y}$ component at 13:50 UT, from $\mathrm{B}_{y}$ positive to $\mathrm{B}_{y}$ negative.

The observed multi-cell flow pattern observed in the Northern Hemisphere consisted of two high-latitude reverse convection cells with sunward flow over the pole, and two lower-latitude standard flow cells with anti-sunward flow. Reverse convection cells observed during northward IMF are indicative of lobe merging, as described by Dungey (1963). Data from the DMSP F13 spacecraft indicates that the two standard cells could lie on closed field lines. During interval $\mathrm{B}$ pulses of reverse convection were clearly observed by the Kapuskasing and Iceland East radars (Fig. 16). The pulsed flows had a periodicity of $\sim 25 \mathrm{~min}$. The flow bursts were associated with a stepwise poleward retraction of the equatorward boundary of radar backscatter. Similar bursts of reverse convection and a stepwise poleward motion of radar backscatter have previously been observed by Sandholt et al. (2000). These authors reported a case study of an interval containing a rapid northward turning of the IMF. This northward turning was accompanied by a long stepwise poleward retraction and latitudinal widening of the band of auroral emission in the Northern Hemisphere cusp region. Data from selected Northern Hemisphere SuperDARN radars demonstrated that the auroral poleward motion was associated with bursts of reverse two-cell convection, and a stepwise poleward motion of the radar backscatter. They concluded that the observations were consistent with a theoretical description of a sequence of bursts of lobe merging involving both hemispheres, resulting in closed flux being added to the dayside magnetosphere. We believe the same process to be occurring here. The retraction of the equatorward boundary of radar backscatter is consistent with the lobe reconnection occurring in both hemispheres, adding closed flux to the dayside magnetosphere (Cowley, 1981, 1983; Cowley and Lock- 
wood, 1992). The fact that the retraction of the radar backsactter is occurring in a stepwise manner is due to the bursty nature of the lobe reconnection.

It is not necessary for lobe reconnection to occur simultaneously in both hemispheres. As illustrated in Fig. 1, lobe reconnection can occur first in one hemisphere and then later in the other. The net result is the formation of a closed dayside field line, and completely detached field lines in the tail. In this study one might assume that the Northern Hemisphere is the favoured hemisphere for lobe reconnection, because even though our interval is close to the northern winter solstice, there is a strong negative IMF $\mathrm{B}_{x}$ component. As already discussed in the introduction, Cowley (1983) argues that if the IMF is pointed antisunward, the Northern Hemisphere will be the favoured hemisphere for reconnection as the geomagnetic field will be anti-parallel to the IMF in this hemisphere. Cowley (1983) indicated that reconnection in the unfavoured hemisphere may then be activated at a later stage. It is unfortunate that the lack of Southern Hemisphere radar data precludes us from ascertaining the large-scale high-latitude convection pattern in the Southern Hemisphere, which would enable us to determine whether the observed lobe merging is simultaneous in the two hemispheres, or sequential.

The bursts of lobe reconnection had a repetition rate which was significantly longer than the periodicity of the flux transfer events in interval A. We do not know the reason for this. A preliminary study of the solar wind conditions during intervals $\mathrm{A}$ and $\mathrm{B}$, using data from the ACE spacecraft (not shown) does not show any significant changes in the nature of the solar wind between the two intervals. Pulsed reconnection occurring during northward IMF intervals has previously been discussed by Rodger et al. (2000), who outlined some of the implications of assuming that reconnection occurring in regions where the magnetosheath flow is super-Alfvenic must be transient. They used a simple magnetospheric model to illustrate where magnetopause reconnection is most likely to occur, and showed that the location of these regions is dependent critically on the dipole tilt angle and the interplanetary conditions. As the clock angle rotates away from $180^{\circ}$, the ratio of transient to quasi-steady reconnection increases. The authors stated that for purely northward IMF conditions reconnection is almost always likely to be transient.

\section{Summary}

We have performed a detailed case study of global plasma convection observed during an interval of prolonged Northward IMF. We combined map-potential global convection patterns derived from the SuperDARN radar data with DMSP cross-track plasma drift vectors and DMSP particle precipitation patterns. Our main observations are as follows.

1. During interval $A$ when the magnitude of the IMF $\mathrm{B}_{y}$ component was comparable with or greater than the IMF $\mathrm{B}_{z}$ component, a distorted standard two-cell convection pattern was observed in both the Northern and
Southern hemispheres. In the Northern Hemisphere we observed a lobe convection cell in the centre of the dusk merging cell, and possibly a narrow viscous cell located equatorward of this lobe cell.

2. Under these conditions pulsed ionospheric flows were observed in the Northern and Southern Hemisphere cusp region with a periodicity of $\sim 15 \mathrm{~min}$. The equatorward boundary of radar backscatter in the Northern Hemisphere progressed equatorward in a stepwise manner approximately every $15 \mathrm{~min}$. We infer that during interval A flux transfer events were occurring at the dayside magnetopause, resulting in open magnetic flux being added to the dayside magnetosphere.

3. The observations made during interval $A$ are consistent with the large IMF $\mathrm{B}_{y}$ component creating a magnetic shear at the dayside magnetopause sufficient for reconnection to occur on closed field lines located equatorward of the open-closed field line boundary, simultaneously to merging in the high-latitude lobe regions.

4. During interval $B$ the IMF $B_{z}$ component was generally larger than the IMF $\mathrm{B}_{y}$ component. In the Northern Hemisphere a multi-cell flow pattern with four flow cells was observed. The re-configuration time was $\sim 25 \mathrm{~min}$, though the IMF showed significant variation also during this interval. The two high-latitude flow cells were "reverse" convection cells with sunward flow over the polar-cap. The two lower-latitude flow cells were 'standard' convection cells associated with antisunward flow at high-latitude and sunward flow at lower latitude. It has not been possible to draw conclusions about the plasma flow in the Southern Hemisphere, as very little backscatter was observed in this hemisphere during interval $\mathrm{B}$.

5. During interval B pulsed reverse flows were observed. These pulses had a periodicity of $\sim 25 \mathrm{~min}$, which is significantly longer that the periodicity of the pulsed flows observed during interval A. The pulses corresponded with stepwise poleward retractions of the equatorward boundary of the Northern Hemisphere radar backscatter.

6. The observations made during interval B are consistent with bursts of lobe reconnection occurring in both hemispheres, resulting in bursts of reverse ionospheric convection and the stepwise poleward retraction of the polar-cap boundary as closed magnetic flux is added to the dayside magnetosphere.

Overall, this case study demonstrates that during an interval of northward IMF the relative magnitudes of the IMF $\mathrm{B}_{y}$ and $\mathrm{B}_{z}$ components determined the latitudes of the reconnection sites between the IMF and the Earth's magnetosphere. Both low-latitude and lobe reconnection were pulsed, and resulted in a stepwise motion of the open-closed field line boundary. Interestingly, when only lobe reconnection was 
observed the bursts of reconnection had a significantly longer periodicity than when simultaneous lower-latitude and lobe merging occurred.

Acknowledgements. We would like to thank the PIs of the SuperDARN radars for provision of the radar data employed in this study. The data employed were from radars funded by research funding agencies of Canada, France, Japan, the UK and the USA. The CUTLASS radar is supported by the Particle Physics and Astronomy Research Council (PPARC grant PPA/R/R/1997/00256), UK, the Swedish Institute for Space Physics, Uppsala, and the Finnish Meteorological Institute, Helsinki. We would also like to thank M. Ruohoniemi from John Hopkins University Applied Physics Laboratory for provision of the "Map Potential" algorithm software. For provision of the ACE magnetometer data we thank N. Ness and C. Smith of the Bartol Research Institute. We wish to thank P. T. Newell for providing DMSP particle data. We gratefully acknowledge the Center for Space Sciences at the University of Texas at Dallas and the US Air Force for providing the DMSP thermal plasma data. GP was supported during this study by PPARC grant PPA/G/O/2003/00013. SWHC was supported during this study by PPARC Senior Fellowship PPA/N/A/2000/00197. AG was supported during this study by PPARC grant PPA/G/0/2003/00013. During part of the preparation of the manuscript ML was supported by the Institute for Advanced Study, La Trobe University, Melbourne, Australia.

The editor in chief thanks P. E. Sandholt and another referee for their help in evaluating this paper.

\section{References}

Burch, J. L., Reiff, P. H., Menietti, J. D., Heelis, R. A., Hanson, W. B., Shawhan, S. D., Shelley, E. G., Sugiura, M, Weimer, D. R., and Winnigham, J. D.: IMF $\mathrm{B}_{y}$-dependent plasma flow and Birkeland currents in the dayside magnetosphere, 1, Dynamic Explorer observations, J. Geohys. Res., 90, 1577-1593, 1985.

Burke, W. J., Kelley, M. C., Sagalyn, R. C., Smiddy, M., and Lai, S. J.:Polar cap electric field structures with a northward interplanetary magnetic field, Geophys. Res. Lett., 6, 21-26, 1979.

Clauer, C. R. and Friis-Christensen, E.: High-latitude dayside electric fields and currents during strong northwards interplanetary magnetic field: Observation and model simulation, J. Geophys. Res., 93, 2749-2757, 1988.

Cowley, S. W. H.: Magnetospheric and ionospheric flow and the interplanetary magnetic field. The Physical Basis of the Ionosphere in the Solar-Terrestrial System, AGARD Conf. Publ., AGARDCP-295, 4/1-4/14, 1981.

Cowley, S. W. H.: Interpretation of observed relations between solar-wind characteristics and effects at ionospheric altitudes, in High Latitude Space Plasma Physics, edited by: B. Hultqvist and T. Hagfors, 225-249, Plenum, New York, 1983.

Cowley, S. W. H. and Lockwood M.: Excitation and decay of solar wind-driven flows in the magnetosphere-ionosphere, Ann. Geophys., 10, 103-115, 1992.

Crooker, N. U.: Dayside merging and cusp geometry, J. Geophys. Res., 84, 951-959, 1979.

Crooker, N. U.: Reverse convection, J. Geophys. Res., 97, $19363-$ 19372, 1992.

Crooker, N. U. and Rich F. J.: Lobe cell convection as a summer phenomenon, J. Geophys. Res., 98, 13 404-13 407, 1993.

Cumnock, J. A., Heelis, R. A., and Hairston, M. R.: Response of the ionospheric convection pattern to a rotation of the interplanetary magnetic field on 14 January 1988, J. Geophys. Res., 97, 19449$19460,1992$.

Dungey, J. W.: The structure of the exosphere, or adventures in velocity space, in Geophysics: The Earth's Environment, edited by: C. DeWitt, J. Hiebolt and A. Lebeau, 526-535, Gordon and Breach, Newark, N. J., 1963.

Elphic, R. C., Lockwood, M., Cowley, S. W. H., and Sandholt, P. E.: Signatures of flux transfer events at the dayside magnetopause and in the ionosphere: Combined ISEE, EISCAT and optical observations, Geophys. Res, Lett, 17, 2241-2244, 1990.

Eriksson, S., Bonnell, J. W., Blomberg, L. G., Ergun, R. E., Marklund, G. T., and Carlson, C. W.: Lobe cell convection and fieldaligned currents poleward of the region 1 current system, J. Geophys. Res., 107, doi:10.1029/2001JA005041, 2002.

Eriksson, S., Peria, W. J., Bonnell, J. W., Su, Y.-J., Ergun, R. E., Tung, Y.-K., Parks, G. K., and Carlson, C. W.: Lobe cell convection and polar-cap precipitation, J. Geophys. Res., 108, doi:10.1029/2002JA009725, 2003.

Freeman, M. P., Farrugia, C. J., Burlaga, L. F., Hairston, M. R., Greenspan, E., Ruohoniemi, J. M., and Lepping, R. P.: The interaction of a magnetic cloud with the Earth: Ionospheric convection in the northern and southern hemispheres for a wide range of quasi-steady interplanetary magnetic conditions, J. Geophys. Res., 98, 7633-7655, 1993.

Frey, H. U., Mende, S, B., Fuselier, S. A., Immel, T. J., and Østgaard, N.: Proton aurora in the cusp during southward IMF, J. Geophys. Res., 108, doi:10.1029/2003JA009861, 2003.

Gosling, J. T., Thomsen, M. F., Bame, S. J., Elphic, R. C., and Russell, C. T.: Observations of reconnection of interplanetary and lobe magnetic field lines at the high-latitude magnetopause, J. Geophys. Res., 96, 14 097-14 106, doi:10.1029/91JA01139, 1991.

Greenwald, R. A., Bristow, W. A., Sofko, G. J., Senior, C., Cerisier, J.-C., and Szabo, A.: Super dual auroral radar network radar imaging of dayside high-latitude convection under northward interplanetary magnetic field: Toward resolving a distorted twocell versus multicell controversy, J. Geophys. Res., 100, 19661$19674,1995$.

Grocott, A., Cowley, S. W. H., Sigwarth, J. B., Watermann, J. F., and Yeoman, T. K.: Excitation of twin-vortex flow in the nightside high-latitude ionosphere during an isolated substorm, Ann. Geophys., 20, 1577-1601, 2002,

SRef-ID: 1432-0576/ag/2002-20-1577.

Grocott, A, Cowley, S. W. H., and Sigwarth, J. B.: Ionospheric flows during extended intervals of northward but $\mathrm{B}_{y}$-dominated IMF, Ann. Geophys., 21, 509-538, 2003.

Haerendel, G., Paschmann, G., Sckopke, N., Rosenbauer, H., and Hedgecock, P. C.: The frontside boundary layer of the magnetopause and the problem of reconnection, J. Geophys. Res., 83, 3195-3296, 1978.

Hardy, D. A., Schmitt, L. K., Gussenhoven, M. S., Marshall, F. J., Yeh, H. C., Shumaker, T. L., Hube, A., and Pantazis, J.: Precipitating electron and ion detectors (SSJ/4) for the block 5-D/flights 6-10 DMSP satellites: Calibration and data presentation, Rep. AFGL-TR-84-0317, Air Force Geophys. Lab, Hanscom Air Force Base, Mass., 1984.

Heppner, J. P. and Maynard, N. C.: Empirical high-latitude electric field models, J. Geophys. Res., 92, 4467-4489, 1987.

Jørgensen, T. S., Friis-Christnsen, E., and Wilhjelm, J.: Interplanetary magnetic field direction and high-latitude ionospheric currents. J. Geophys. Res., 77, 1976-1977, 1972. 
Kessel, R. L., Chen, S.-H., Green, J. L., Fung, S. F., Boardsen, S. A., Tan, L. C., Eastman, T. E., Craven, J. D., and Frank, L. A.: Evidence of high-latitude reconnecting during northward IMF: Hawkeye observations, Geophys. Res. Lett., 23, 583-586, doi:10.1029/95GL03083, 1996.

Knipp, D. J., Richmond, A. D., Emery, B., Crooker, N. U., de la Beaujardiere, O., Evans, D., and Kroehl, H.: Ionospheric convection response to changing IMF direction, Geophys. Res. Lett., 18(4), 721-724, doi:10.1029/90GL02592, 1991.

Knipp, D. J., Emery, B. A., Richmond, A. D. et al.: Ionospheric convection response to slow, strong variations in a northward interplanetary magnetic field: A case study for 14 January 1988, J. Geophys. Res, 98, 19271-19292, 1993.

Lester, M., Beujardière, O. de la, Foster, J. C., Freeman, M. P., Lühr, H., Ruohoniemi, J. M., and Swider, W.: The response of the large-scale ionospheric convection pattern to changes in the IMF and substorms: Results from the SUNDIAL 1987 campaign, Ann. Geophys., 11, 556-571, 1993.

Lockwood, M., Sandholt, P. E., Farmer, A. D., Cowley, S. W. H., Lybekk, B, and Davda, V. N.: Auroral and plasma flow transients at magnetic noon, Planet. Space Sci., 38, 973-993, 1990.

Lockwood, M and Moen, J.: Reconfiguration and closure of lobe flux by reconnection during northward IMF: possible evidence for signatures in cusp/cleft auroral emissions, Ann. Geophys., 17 , 996-1011, 1999.

Lyons, L. R., Lu, G, de la Beaujardiere, O., and Rich, F. J.: Synoptic maps of polar caps for stable interplanetary magnetic field intervals during January 2002 geospace environment modeling campaign, J. Geophys. Res., 101, 27 283-27 298, 1996.

McWilliams, K. A., Yeoman, T. K., and Provan, G.: A statistical survey of dayside pulsed ionospheric flows as seen by the CUTLASS Finland HF radar, Ann. Geophys., 18, 445-453, 2000.

Milan, S. E., Yeoman, T. K., and Lester, M.: The dayside auroral zone as a hard target for coherent HF radars, Geophys. Res. Lett, 25, 3717-3720, 1998.

Milan, S. E., Lester, M., Cowley, S. W. H., Moen, J., Sandholt, P. E, and Owen, C. J.: Meridian-scanning photometer, coherent HF radar, and magnetometer observations of the cusp: a case study, Ann. Geophys., 17, 159-172, 1999.

Milan, S. E., Lester, M., Cowley, S. W. H., and Brittnacher, M.: Convection and auroral response to a southward turning of the IMF: Polar UVI, CUTLASS, and IMAGE signatures of transient magnetic flux transfer at the magnetopause, J. Geophys. Res., 105(A7), 15 741-15 756, doi:10.1029/2000JA900022, 2000.

Phan, T. D., Lin, R. P., Fuselier, S. A., Fujimoto, M.: Wind observations of mixed magnetosheath-plasma like ions deep inside the magnetosphere, J. Geophys. Res, 105, 5497-5505, 2000.

Pinnock, M., Rodger, A. S., Dudeney, J. R., Rich, F., and Baker, K. B.: High spatial and temporal resolution observations of the ionospheric cusp, Ann. Geophys., 13, 919-925, 1995.

Potemra, T. A., Zanetti, L. J., Bythrow, P. F., and Lui, A. T. Y.: B dependent convection patterns during northwards interplanetary magnetic field, J. Geophys. Res., 89, 9753-9760, 1984.

Provan, G., Yeoman, T. K., and Milan, S. E.: CUTLASS Finland radar observations of the ionospheric signatures of flux transfer events and the resulting plasma flows, Ann. Geophys., 16, 14111421, 1998.
Reiff, P. H. and Heelis, R. A.: Four cells or two? Are four convection cells really necessary? J. Geophys. Res., 99, 3955-3959, 1994.

Reiff, P. H. and Burch, J. L.: $\mathrm{B}_{y}$-dependent dayside plasma flow and Birkeland currents in the dayside magnetosphere, 2, A global model for northward and southward IMF, J. Geophys. Res., 90, 1595-1609, 1985.

Rijnbeek, R. P., Cowley, S. W. H, Southwood, D. J., and Russell, C. T.: A survey of dayside flux transfer events using ISEE 1 and 2 magnetometers, J. Geophys. Res., 89, 786-800, 1984.

Rodger, A. S., Mende, S. B., Rosenberg, T. J. and Baker, K.: Simultneous optical and HF radar observations of the ionospheric cusp, Geophys. Res. Lett., 22, 2045-2048, 1995.

Rodger, A. S. and Pinnock, M.: The ionospheric response to flux transfer events: the first few minutes, Ann. Geophys., 15, 685691, 1997.

Rodger, A. S., Coleman, I. J., and Pinnock, M.: Some comments on transient and steady-state reconnection at the dayside magnetopause, Geophys. Res. Lett., 27(9), 1359-1362, doi:10.1029/1999GL010758, 2000.

Ruohoniemi, J. M. and Greenwald, R. A.: Statistical patterns of high-latitude convection obtained from Goose Bay HF radar observations, J. Geophys. Res., 101, 21 743-21 764, doi:10.1029/96JA01584, 1996.

Ruohoniemi, J. M. and Baker, K. B.: Large-scale imaging of highlatitude convection with Super Dual Auroral Radar Network HF radar observations, J. Geophys. Res., 103, 20 797-20811, doi:10.1029/98JA01288, 1998.

Russell, C. T.: The configuration of the magnetosphere, in Critical Problems of Magnetospheric Physics, edited by: E. R. Dyer, 1-16, Inter-Union Commission on Solar-Terrestrial Physics Secretariat, National Academy of Sciences, Washington, D.C., 1972.

Russell, C. T., and Elphic, R. C., Initial ISEE magnetometer results: Magnetopause observations, Space Sci. Rev., 22, 681, 1978.

Russell, C. T. and Elphic, R. C.: ISEE observations of flux transfer events at the dayside magnetopause, Geophys. Res. Lett., 6, 33 , 1979.

Sandholt, P. E., Lybekk, B., Egeland, A., Nakamura, R., and Oguti, T.: Midday auroral breakup, J. Geomag. Geoelectr., 41, 371-387, 1989.

Sandholt, P. E., Farrugia, C. J.,Moen, J., and Cowley, S. W. H.: Dayside auroral configurations: Responses to southward and northward rotations of the interplanetary magnetic field., J. Geophys. Res., 103, 20 279-20 295, 1998.

Sandholt, P. E., Farrugia, C. J., Cowley, S. W. H, Lester, M., Denig, W. F., Cerisier, J.-C., Milan, S. E., Moen, J., Trondsen, E. and Lybekk, B.: Dynamic cusp aurora and associated pulsed reverse convection during northward interplanetary magnetic field, J. Geophys. Res., 105, 12 869-12 894, 2000.

Smith, C. W., Acuna, M. H., Burlaga, L. F., L'Heureux, J., Ness, N. F., and Scheifele, J.: The ACE magnetic field experiment, Space Science Reviews, 86, 613-632, 1999.

Østgaard, N., Mende, S. B., Frey, H. U., Frank, L. A., and Sigwarth, J. B.: Observations of non-conjugate theta aurora, Geophys. Res. Lett., 30(21), 2125, doi:10.1029/2003/GL017914, 2003. 